\title{
Differential impacts of climate change on the hydrology of two alpine river basins
}

\author{
Karsten Jasper ${ }^{1, *}$, Pierluigi Calanca ${ }^{1}$, Dimitrios Gyalistras ${ }^{2}$, Jürg Fuhrer ${ }^{1}$ \\ ${ }^{1}$ Swiss Federal Research Station for Agroecology and Agriculture (FAL), Air Pollution/Climate Group, 8046 Zürich, Switzerland \\ ${ }^{2}$ University of Bern, Institute of Geography, 3012 Berne, Switzerland
}

\begin{abstract}
Earlier impact studies have suggested that climate change may severely alter the hydrological cycle in alpine terrain. However, these studies were based on the use of a single or a few climate scenarios only, so that the uncertainties of the projections could not be quantified. The present study helps to remedy this deficiency. For 2 Alpine river basins, the Thur basin $\left(1700 \mathrm{~km}^{2}\right)$ and the Ticino basin $\left(1515 \mathrm{~km}^{2}\right)$, possible future changes in the natural water budget relative to the 1981-2000 (Thur) and 1991-2000 (Ticino) baselines were investigated by driving the distributed catchment model WaSiM-ETH with a set of 23 regional climate scenarios for monthly mean temperature $(T)$ and precipitation $(P)$. The scenarios referred to 2081-2100 and were constructed by applying a statistical-downscaling technique to outputs from 7 global climate models. The statisticaldownscaling scenarios showed changes in annual mean $T$ between +1.3 and $+4.8^{\circ} \mathrm{C}$ and in annual total $P$ between -11 and $+11 \%$, with substantial variability between months and catchments. The simulated overall changes in the hydrological water cycle were qualitatively robust and independent of the choice of a particular scenario. In all cases, the projections showed strongly decreased snowpack and shortened duration of snow cover, resulting in time-shifted and reduced runoff peaks. Substantial reductions were also found in summer flows and soil-water availability, in particular at lower elevations. However, the magnitudes and certain aspects of the projected changes depended strongly on the choice of scenario. In particular, quantitative projections of soil moisture in the summer season and of the runoff in both the summer and autumn seasons were found to be quite uncertain, mainly because of the uncertainty present in the scenarios for $P$. Our findings clearly demonstrate that quantitative assessments of hydrological changes in the Alps using only a small number of scenarios may yield misleading results. This work strengthens our confidence in the overall results obtained in earlier studies and suggests distinct shifts in future Alpine hydrological regimes, with potentially dramatic implications for a wide range of sectors.
\end{abstract}

KEY WORDS: Climate change impact $\cdot$ Regional climate scenarios $\cdot$ Uncertainty analysis $\cdot$ Mountain hydrology $\cdot$ Distributed hydrological modeling $\cdot$ WaSiM-ETH

Resale or republication not permitted without written consent of the publisher

\section{INTRODUCTION}

Climate change and associated impacts on water resources are of prime concern for societies because of their implications for socio-economic systems, such as agriculture and forestry, semi-natural ecosystems, and infrastructures. The results reported in the Third Assessment Report of the Intergovernmental Panel on Climate Change (IPCC) (Houghton et al. 2001, McCarthy et al. 2001) indicate an increase in global mean temperature ranging from 1.4 to $5.8^{\circ} \mathrm{C}$ for the end of the 21st century. Concurrently, it is expected that global mean precipitation will increase by about $2.4 \%$ per $1{ }^{\circ} \mathrm{C}$ increase in temperature, on average. While possible climatic changes have been studied to some extent in recent times, hydrological responses on these changes are still poorly documented, in particular for river catchments at the hydrological mesoscale (Menzel et al. 2002).

Estimates of future changes in climatic and hydrological conditions are complicated by an array of uncertainties related to the unknown future evolution 
of climate-forcing agents (emissions) (Nakicenovic \& Swart 2000) and the limitations of the global to regional climate models used to project possible regional climate future. Moreover, hydrological projections are particularly demanding for river basins located in complex terrain such as the European Alps because of strong variations in landscape, climatic and hydrological conditions (e.g. Gurtz et al. 1999, 2003, Menzel et al. 1999, Frei et al. 2001, Jasper 2001, Schwarb et al. 2001, Schmidli et al. 2002, Verbunt et al. 2003). Distributed hydrological models are required to reflect this diversity and to investigate the temporal and spatial effects of climate change on the water budget and runoff dynamics.

So far only a few model studies have reported estimates of the impact of climate change on the hydrological conditions in the Swiss Alps (e.g. Gurtz et al. 1997, Schulla 1997, Schaper \& Seidel 2001, Kleinn 2002). These studies found that changed climatic conditions will strongly reflect in changes in water balances and in frequency distributions of floods and low flows. The results presented internally consistent projections of possible future hydrological conditions that might occur if all the underlying assumptions became true. However, little is currently known about the robustness of the projections. In particular, sensitivity studies have revealed that small differences in various input parameters and driving meteorological variables can lead to large changes in the hydrological response (e.g. Jasper et al. 2002). A major problem with the existing studies is that they have considered only a very limited sample of climate-change scenarios, which did not account for the wide uncertainty band for the future evolution of the Alpine climate that has been found in reviews of Alpine climate scenarios by Gyalistras et al. (1998) and Gyalistras (2000).

The present work focuses on the variability in regional climate projections as one important source of uncertainty for hydrological projections in the Alps. The aim of the present study was 2-fold: (1) to test whether the main results of the few existing studies remain valid under a wider range of assumptions regarding the evolution of the Alpine climate; and (2) to provide quantitative estimates and error bands for the possible effects of a changing climate on selected aspects of the hydrological response in the Alps.

We use a well-validated distributed hydrological model and a large set of state-of-the-art regional climate scenarios reflecting the main uncertainties related to the future evolution of the global and regional climate systems. The focus is on changes in the long-term mean water balance at the catchment scale. We account for the climatic gradient across the Alps by considering 2 Swiss alpine river basins, one to the north and the other to the

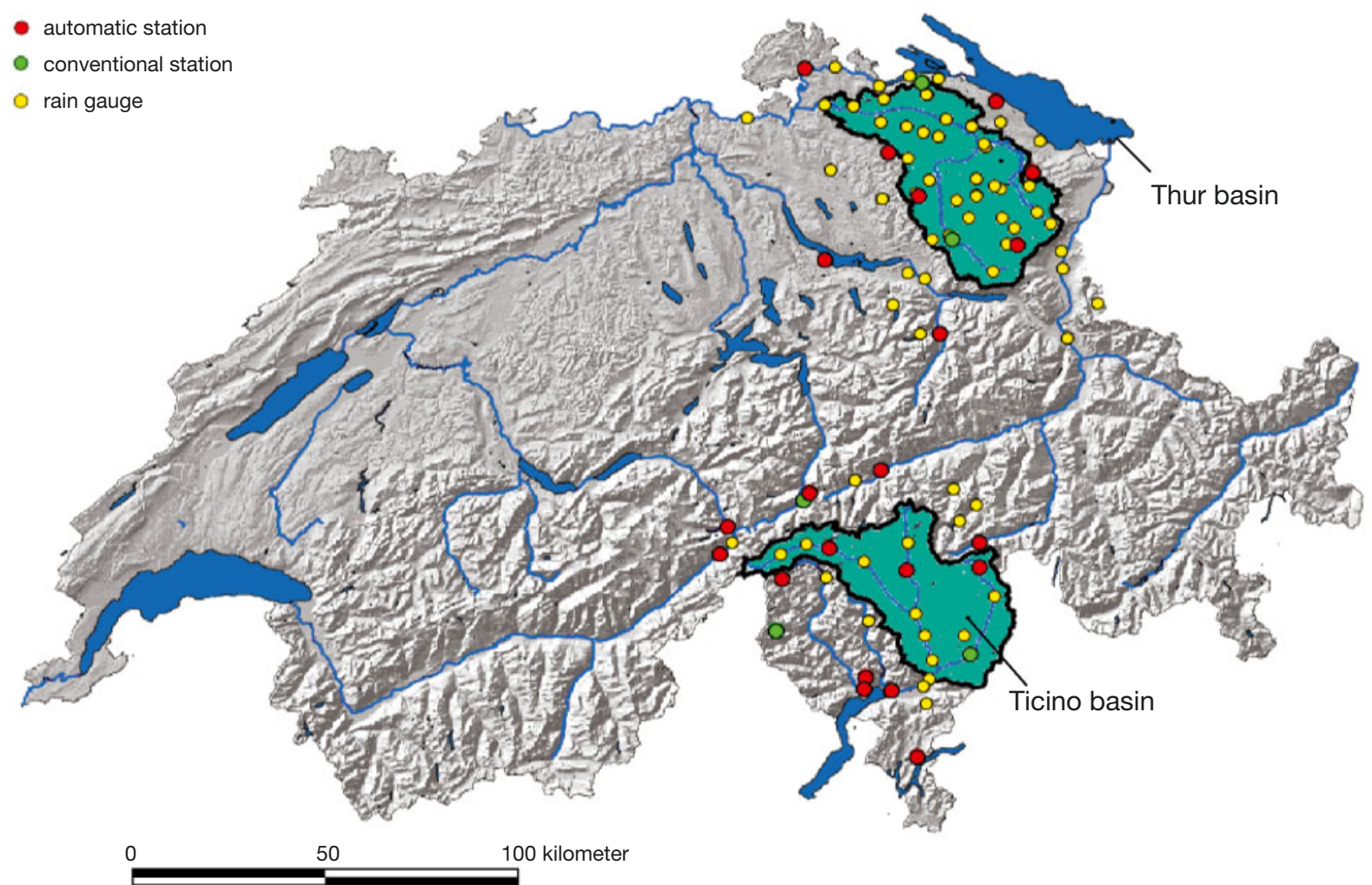

Fig. 1. Location of the 2 study areas in Switzerland and of the meteorological stations used for the hydrological simulations (control runs) 
south of the main ridge. Our results suggest a quite robust pattern of hydrological response to global warming in the Swiss Alps, but also reveal some major limitations related to the quantification of this response.

\section{DATA AND METHODS}

\subsection{Study areas and meteorological data}

The areas selected for this study were (1) the Thur river basin (tributary of the Rhine) in northeastern Switzerland, and (2) the basin of the upper Ticino river on the southern slopes of the Alps (Fig. 1, Table 1). Both basins are characterized by pronounced physiographic heterogeneity and by strong variations of the climatic and hydrological conditions. The Thur basin represents a typical catchment of the northern Alps and their forelands. From the steep mountainous 'Alpstein' region the Thur heads north(west) through the moderately reliefed alpine foreland. The altitudinal area distribution (Fig. 2a) indicates the dominance of midland character (areas lower than $1000 \mathrm{~m}$ ). The Thur basin is primarily used by agriculture. Loam has been identified as the prevailing soil texture.

The second area of investigation, the upper Ticino basin, is characterized by extreme topographic conditions; the mean slope of this basin exceeds that of the Thur basin by a factor of 3 . Fig. $2 \mathrm{~b}$ shows that more than $80 \%$ of the Ticino area is located higher than $1000 \mathrm{~m}$ a.s.l. Due to the dominance of high alpine area characteristics, mainly forested and rocky areas are found in the Ticino basin. The prevailing soil texture is loamy sand. The Ticino area is affected, on the one hand, by exceptional precipitation amounts and intensities leading to relatively frequent flood events (e.g. Frei et al. 2001), and, on the other hand, by occasional seasonal drought periods.

Meteorological observation data were made available by the Swiss Federal Office for Meteorology (MeteoSwiss). The data series covered a $10 \mathrm{yr}$ period for the Ticino basin (1991-2000) and a $20 \mathrm{yr}$ period for the Thur basin (1981-2000), respectively. Fig. 1 shows that the selected stations can be divided into automatic stations (hourly values), conventional stations ( 3 readings $\mathrm{d}^{-1}$ ), and simple rain gauges (daily sums). Both automatic and conventional stations provide data for precipitation, temperature and wind speed, whereas radiation, sunshine duration and watervapor pressure are only available from the automatic stations.
Table 1. Basic geographical, land-use, climate and runoff characteristics of the river basins of Thur and Ticino

\begin{tabular}{|lccc|}
\hline & & $\begin{array}{c}\text { Thur } \\
\text { basin }\end{array}$ & $\begin{array}{c}\text { Ticino } \\
\text { basin }^{\mathrm{b}}\end{array}$ \\
\hline Topography & & & \\
Area & $\left(\mathrm{km}^{2}\right)$ & 1700 & 1515 \\
Altitude range & $(\mathrm{m}$ a.s.l. $)$ & $356-2504$ & $220-3402$ \\
Mean altitude & $(\mathrm{m}$ a.s.l. $)$ & 769 & 1680 \\
Mean slope & $\left({ }^{\circ}\right)$ & 9.1 & 27.9 \\
Land-use/soil cover & & & \\
Water & $(\%)$ & 0.7 & 1.7 \\
Settlement & $(\%)$ & 8.9 & 2.3 \\
Forest & $(\%)$ & 28.8 & 44.8 \\
Horticulture & $(\%)$ & 3.1 & 0.2 \\
Farmland & $(\%)$ & 19.3 & 0.2 \\
Grassland & $(\%)$ & 36.0 & 16.2 \\
Shrubs & $(\%)$ & 1.1 & 15.1 \\
Rock & $(\%)$ & 0.8 & 18.9 \\
Glacier & $(\%)$ & 0.0 & 0.7 \\
Runoff & & \\
Minimum & & & \\
Mean & $\left(\mathrm{m}^{3} \mathrm{~s}^{-1}\right)$ & 2.24 & 10.6 \\
Maximum & $\left(\mathrm{m}^{3} \mathrm{~s}^{-1}\right)$ & 47.0 & 68.7 \\
Climate & $\left(\mathrm{m}^{3} \mathrm{~s}^{-1}\right)$ & 1130 & 1500 \\
Annual mean & & & \\
temperature & & & \\
Annual precipitation & $\left(\mathrm{mm}^{\circ}\right)$ & 1470 & 1820 \\
a Stream gauge: Andelfingen & & \\
b Stream gauge: Bellinzona & & \\
cFrom FOWG $(2000)$ & & & \\
\hline
\end{tabular}

\subsection{The hydrological model}

Simulations were carried out using the grid-based catchment model WaSiM-ETH (Water Flow and Balance Simulation Model; Schulla 1997, Schulla \& Jasper 2000). From the hydrological point of view of spatially distributed catchment modeling, this model represents the state-of-the-art. The model's flexibility allows both
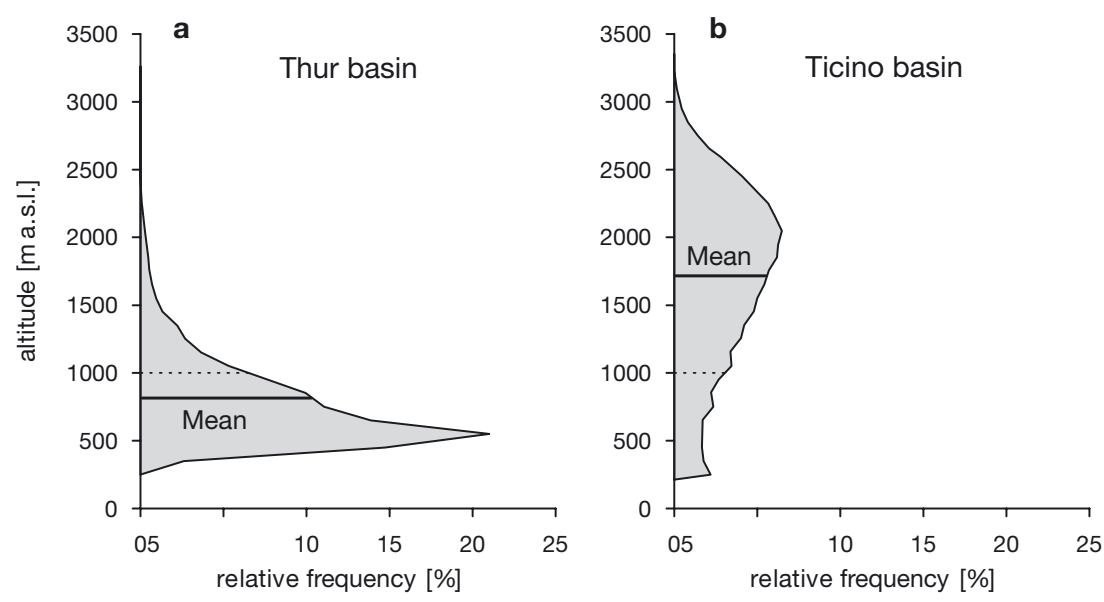

Fig. 2. Altitude distribution for the (a) Thur and (b) Ticino river basins 
short-term (flood runoff) and long-term (water balance) simulations. Model experiences show that WaSiMETH can be successfully applied to a wide range of scales, from lysimeter sites to macroscale river basins (e.g. Jasper 2001, Kleinn 2002, Gurtz et al. 2003). The main model components are as follows:

- temporal and spatial interpolation of meteorological input data (Schulla 1997)

- error correction of precipitation measurements for rain and snow (Sevruk 1986)

- shading and topographic-dependent (aspect, slope) adjustment for radiation and temperature (Oke 1987)

- interception storage and evaporation

- potential and actual evapotranspiration (Monteith 1975)

- snow accumulation and snowmelt (Braun 1985)

- glacier melt and runoff (Klok et al. 2001)

- infiltration and surface-runoff generation (Green \& Ampt 1911)

- soil-water storage, percolation and interflow generation

- soil-water extraction by evapotranspiration

- groundwater recharge and storage as well as groundwater runoff generation (baseflow)

- runoff concentration, discharge and flood rooting.

\subsubsection{Evapotranspiration, soil-water dynamics and runoff generation}

Actual evapotranspiration (ET) is derived from the potential evapotranspiration (PET) by taking into account the influence of soil-water content (SWC):

$$
\begin{aligned}
& \mathrm{ET}=\mathrm{PET} \cdot \frac{\mathrm{SWC}_{\mathrm{act}}-\mathrm{SCW}_{\mathrm{wp}}}{\mathrm{SWC}_{\mathrm{fc}}-\mathrm{SCW}_{\mathrm{wp}}} \\
& \text { for } \mathrm{SCW}_{\mathrm{wp}} \leq \mathrm{SWC}_{\mathrm{act}}<\mathrm{SCW}_{\mathrm{fc}}
\end{aligned}
$$

$\mathrm{SWC}_{\mathrm{act}}$ is the actual SWC; $\mathrm{SWC}_{\mathrm{fc}}$ and $\mathrm{SWC}_{\mathrm{wp}}$ denote the SWC at field capacity and at the wilting point, respectively.

The soil model in WaSiM-ETH calculates the infiltration of water into the soil and the surface-runoff generation using the Green-Ampt approach, with estimates of the saturation time after Peschke (1987). A discrete formulation of the Richards equation (Richards 1931) is used to simulate the vertical flow of water in the unsaturated soil zone. Interflow is generated as lateral water flow in predefined soil layers, depending on the hydraulic pressure, the drainable water content, the hydraulic conductivity and gradient, as well as the flow density. Baseflow is determined as exfiltration from the groundwater into the surface river system. The simulation of discharge routing within the river channels based on hydraulic calculations of the flow velocities (kinematic wave approach).

\subsubsection{Model calibration and validation}

The WaSiM-ETH model was calibrated and validated by continuous observation-driven runoff simulations. All simulations were carried out using grid sizes of $1 \times 1 \mathrm{~km}^{2}$ and daily calculation time steps. For the Ticino basin, the model calibration and validation were complicated by hydropower companies' influential control of the natural runoff regime (Martignoni \& Barelli 1997). To take approximately account of this influence, data on reservoir management (values of lake levels, lake-volume changes, diverted water flows and redistributed inflows) were made available and included into the model runs. Note, however, that the simulations carried out later (control and scenario runs) did not consider the impact of storage effects but assumed, for reasons of better comparability, unaffected (natural) runoff conditions.

The quality of model calibration and validation was quantified in terms of the efficiency criterion proposed by Nash \& Sutcliffe (1970) (NSC), which represents a widely used 'goodness-of-fit' measure in hydrological modeling (Legates \& McCabe 1999). It is given by:

$$
\mathrm{NSC}=1-\frac{\sum_{i=1}^{n}\left(x_{i}-y_{i}\right)^{2}}{\sum_{i=1}^{n}\left(x_{i}-\bar{x}\right)^{2}}
$$

with $x$ being, in this case, the observed runoff, $y$ the modeled runoff, $\bar{x}$ the average of all $x$, and $n$ the number of time steps. The value of NSC can range from $-\infty$ to 1.0. A value of zero indicates that the model is not better than a simple prediction obtained by assigning the average $\bar{x}$ to all $x$, while a value of 1.0 stands for a perfect agreement.

The results of model calibration and validation are presented in Table 2. They demonstrate that the model resolution (one day in time and one kilometer in space) is still adequate for reproducing successful runoff and water balance simulations.

\subsection{Climate scenarios}

The climate scenarios used in the present study were based on outputs of coupled atmosphere-ocean general circulation models (AO-GCMs), since these models are generally considered to be 'the most advanced tools currently available for simulating the response of the global climate system to changing atmospheric composition' (Mearns et al. 2001). However, GCMs have a relatively coarse horizontal resolution (on the order of a few 100s of kilometers), which does not resolve the complex topography of the Alps at the 
Table 2. Average Nash-Sutcliffe performance criteria for the periods of model calibration and validation

\begin{tabular}{|lcc|}
\hline Periods (Thur; Ticino) & Thur basin & Ticino basin \\
\hline $\begin{array}{l}\text { Calibration } \\
\text { (1983-1990; 1993-1996) }\end{array}$ & 0.85 & 0.73 \\
$\begin{array}{l}\text { Validation } \\
(1991-2000 ; 1997-2000)\end{array}$ & 0.83 & 0.73 \\
\hline
\end{tabular}

scales which mattered for the present study. Moreover, as we were interested in the differential response of 2 catchments to given changes in climate, we needed scenarios which showed internally consistent spatial patterns of change.

Therefore, we decided to use mainly scenarios which were derived by means of 'statistical downscaling' (Giorgi et al. 2001) of GCM outputs to the regional scale. This approach has been shown to yield generally plausible and spatially consistent scenarios for the Alps (e.g. Gyalistras et al. 1994, 1998). An alternative would have been to use simulations with regional climate models (RegCM). However, RegCMs require huge amounts of input data and are very computer intensive, and at the time this work was undertaken, only a few, and mostly outdated, RegCM-based scenarios were available for Switzerland (see review by Gyalistras 2000).

The statistical-downscaling scenarios were constructed by applying the method of Gyalistras et al. (1994) to a novel $5 \mathrm{~km}$ gridded monthly mean temperature $(T)$ and monthly total precipitation $(P)$ data set (Gyalistras 2003) that covers the entire domain of Switzerland. According to this method, we first established multivariate regression models that related inter-annual variations in the large-scale sea-level pressure (SLP) and near-surface temperature (NST) fields to simultaneous regional climate anomalies on the $5 \mathrm{~km}$ grid. For the prediction of the regional $T$ anomalies we used both SLP and NST, whereas for $P$ we considered only SLP. The use of a large-scale predictor field related to atmospheric humidity would have been desirable, in particular with regard to $P$ (e.g. Charles et al. 1999), but the inclusion of such information was not possible, because no corresponding data were available to us for the GCM scenario runs.

The regression models were estimated by means of a canonical correlation analysis $\left(\mathrm{CCA}_{i}\right.$ e.g. von Storch \& Zwiers 1999) in the space spanned by the first few empirical orthogonal functions (EOFs) of the predictor and predictand variables. The models were calibrated for 1951-1999 using the SLP data set of Trenberth \& Paolino (1980, updated) and the NST data by Jones et al. (2001).
Changes in long-term mean $T$ and $P$ during 2081-2100 relative to the baseline 1961-1990 were obtained by applying the CCA models to GCMsimulated anomalies of SLP and NST. We derived a total of 17 different climate scenarios based on the changes simulated by 7 GCMs and 4 emission scenarios (Table 3). The latter referred to the IPCC emission scenario IS92a (Houghton et al. 1992) and the more upto-date emission scenarios A2 and B2 described in the IPCC Special Report on Emission Scenarios (SRES) (Nakicenovic \& Swart 2000). Note that in our study the IS92a scenario was given in 2 modes: (1) forcing by greenhouse gas only (GG) and (2) forcing by greenhouse gas and sulfate aerosols (GS).

The GCM data were obtained from the IPCC Data Distribution Centre (http://ipcc-ddc.cru.uea.ac.uk). Data preparation is described in Kernen \& Gyalistras (2002). A closer description of the scenarios is given in Gyalistras (2002) (see also Section 3.1). We will refer to the statistical-downscaling scenarios for both $T$ and $P$ as ' $\mathrm{SD}^{\prime}$, for the subset of the statistical-downscaling $T$ or $P$ scenarios as 'SDT' and 'SDP', respectively.

Several reasons lead us to consider some additional scenarios for $P$. First, our $P$ scenarios were based only on SLP and thus might fail to account for the effects of possible changes in other relevant predictors. Second, our statistical-downscaling models showed only modest skill with regard to $P$. The average coefficient of determination from a leave-one-out cross-validation for $T$ was on the order of 0.6 for all months, but for $P$ it was around 0.3 in autumn and winter, and only 0.1 to

Table 3. General circulation models (GCMs) and emission scenarios used to project the changes in temperature and precipitation. CCSR-NIES1: Center for Climate System Research, University of Tokyo - National Institute for Environmental Studies (Japan); CGCM1/2: Canadian Global Coupled Model (2 versions); ECHAM4-OPYC3: ECMWF Model, modified in Hamburg (Germany); DOE PCM: Department of Energy Parallel Climate Model (Boulder, CO, USA); CSIRO: Commonwealth Scientific and Industrial Research Organization (Melbourne, Australia); HadCM3: Hadley Centre Climate Model 3 (Bracknell, UK). GG, GS: IS92a scenarios (Houghton et al. 1992), based on either greenhouse gases only or greenhouse gases and sulfate aerosols; A2, B2: SRES scenarios (Nakicenovic \& Swart 2000)

\begin{tabular}{|lcccc|}
\hline & \multicolumn{4}{c|}{ Forcing } \\
\hline GCM name & GG & GS & A2 & B2 \\
CCSR-NIES1 & $\times$ & $\times$ & & \\
CGCM1 & $\times$ & $\times$ & & \\
CGCM2 & & & $\times$ & $\times$ \\
ECHAM4-OPYC3 & $\times$ & & & \\
DOE PCM & & & $\times$ & $\times$ \\
CSIRO & $\times$ & $\times$ & $\times$ & $\times$ \\
HadCM3 & $\times$ & $\times$ & $\times$ & $\times$ \\
\hline
\end{tabular}


0.2 in summer. Third, the downscaled changes in $P$ were found to be relatively small when compared to the results from other studies: only about $10 \%$ of the seasonal changes in our SDP scenarios amounted to more than $15 \%$, whereas in a comparison of 22 Alpine scenarios (Gyalistras 2000) that were derived using all major scenario construction techniques (including the use of high-resolution GCMs, RegCMs, statisticaldownscaling and grid-point techniques) the proportion of projected changes that amounted to more than $15 \%$ was $30 \%$.

The additional $P$ scenarios were constructed only for a subset of 3 selected SDT scenarios. These were determined as follows: First, we ranked all 17 SDT scenarios based on the areal mean $T$ change for the entire region of Switzerland. The latter varied between 1.2 and $4.1^{\circ} \mathrm{C}$, with an average of $2.5^{\circ} \mathrm{C}$. Then we selected the 4 th (lower quartile of all ranks), 9th (median quartile) and 14th (upper quartile) warmest scenarios. These were the scenarios CSIRO_B2 $\left(1.8^{\circ} \mathrm{C}\right)$, CSIRO_A2 $\left(2.4^{\circ} \mathrm{C}\right)$, and HadCM3_GS $\left(3.4^{\circ} \mathrm{C}\right)$ (cf. Table 3$)$. They will be referred to as 'SDT-low', 'SDT-medium' and 'SDT-high', respectively.

The first set of additional $P$ scenarios was chosen to reflect particularly dry conditions during summer. We focused on summer dryness due to its obvious practical importance and because most GCMs project marked decreases in summer precipitation over Central/Southern Europe (e.g. Giorgi \& Mearns 2002). Thus, we constructed the 'dry-summer' scenarios by simply combining the SDT-low, -medium and -high scenarios with the $P$ changes simulated by the respective GCMs. For this purpose, we considered the average signal from selected grid points (GP) in the vicinity of the European Alps (for details, see Gyalistras 2002). An alternative would have been to interpolate the $P$ changes from surrounding GPs to our case-study regions, but we chose an averaging procedure because the model errors tend to increase with increasing resolution over complex terrain (e.g. Widmann \& Bretherton 2000). The summer mean GP changes from the CSIRO_B, CSIRO_A and HadCM3_GS simulations amounted to $-3,-12$ and $-40 \%$, respectively. The resulting set of combined scenarios was named SDT_GPP.

The second set of additional $P$ scenarios was used to explore the possible hydrological responses to a generally much wetter climate than depicted in the SDP scenarios. For this purpose, for the 22 scenarios reviewed by Gyalistras (2000), we determined the mean seasonal changes in $P$ from all scenarios that showed a positive change in the respective season. These changes amounted to $+16 \%$ (mean from $\mathrm{n}=16$ scenarios) for winter, $+7 \%(\mathrm{n}=11)$ for spring, $+16 \%(n=9)$ for summer, and $+14 \%(n=10)$ for autumn. Thus, we combined the SDT-low, -medium and -high scenarios with an idealized, uniform $15 \%$ increase in $P$ throughout the year. This set of combined scenarios was named SDT_P15.

\subsection{Time slices and model set-up}

As illustrated in Fig. 3, hydrological model experiments were performed for 2 time slices: (1) the reference period (1981-2000 for the Thur basin, and 1991-2000 for the Ticino basin), and (2) the projection period (2081-2100). In the first case, the model was driven by daily weather observations (control run). In the second case, the driving meteorological inputs were changed with respect to $T$ and $P$. For this purpose, the monthly $5 \mathrm{~km}$ SD scenario grids were interpolated onto the $1 \mathrm{~km}$ grid of the hydrological model using bi-cubic spline interpolation. Thereafter, these high-resolution scenarios were linearly interpolated in time by assuming that the monthly scenarios are valid for the 15th day of each month. In result of this procedure, daily $1 \mathrm{~km}$ gridded scenarios of $T$ and $P$ were obtained and could be made available for the hydrological simulations. In switching from the reference period to the 2081-2100 time slice, all other meteorological observation data (wind speed, radiation, sunshine duration) remained unchanged, except for the water-vapor pressure, which was adjusted according to $T$ under the assumption of unchanged relative humidity (see also Section 4).

The parametrization of WaSiM-ETH was based on information derived from 3 gridded GIS data layers: maps of elevation, land surface and soil characteristics (Table 4). Parameter values were mostly taken from published works, e.g. from Carsel \& Parrish (1988), who proposed average values for soil-water retention parameters and saturated hydraulic conductivity for

Table 4. Sources of the GIS databases for hydrological modeling and derived model parameters

\begin{tabular}{|lll|}
\hline Topography & Land use & Soil characteristics \\
\hline $\begin{array}{l}\text { Original data source } \mathbf{( 1 0 0} \mathbf{~} \mathbf{~} \times \mathbf{1 0 0} \mathbf{~} \text { ) } \\
\begin{array}{l}\text { Digital elevation map } \\
\text { (interpolated RIMINI }\end{array}\end{array}$ & $\begin{array}{l}\text { Swiss land-use statistics } \\
\text { model; SFOT 1992) }\end{array}$ & $\begin{array}{l}\text { Digital soil map } \\
\text { (GEOSTAT 1992) }\end{array}$ \\
$\begin{array}{lll}\text { Derived model parameters } \\
\text { River network }\end{array}$ & & \\
Sub-basins & Leaf-area index & Porosity \\
Slope & Rooting depth & Wilting point \\
Aspect & Type of root distribution & Hydraulic conductivity \\
Flow times & Stomatal diffusion & Matrix potential \\
Channel parameters & Aerodynamic resistance & \\
\hline
\end{tabular}




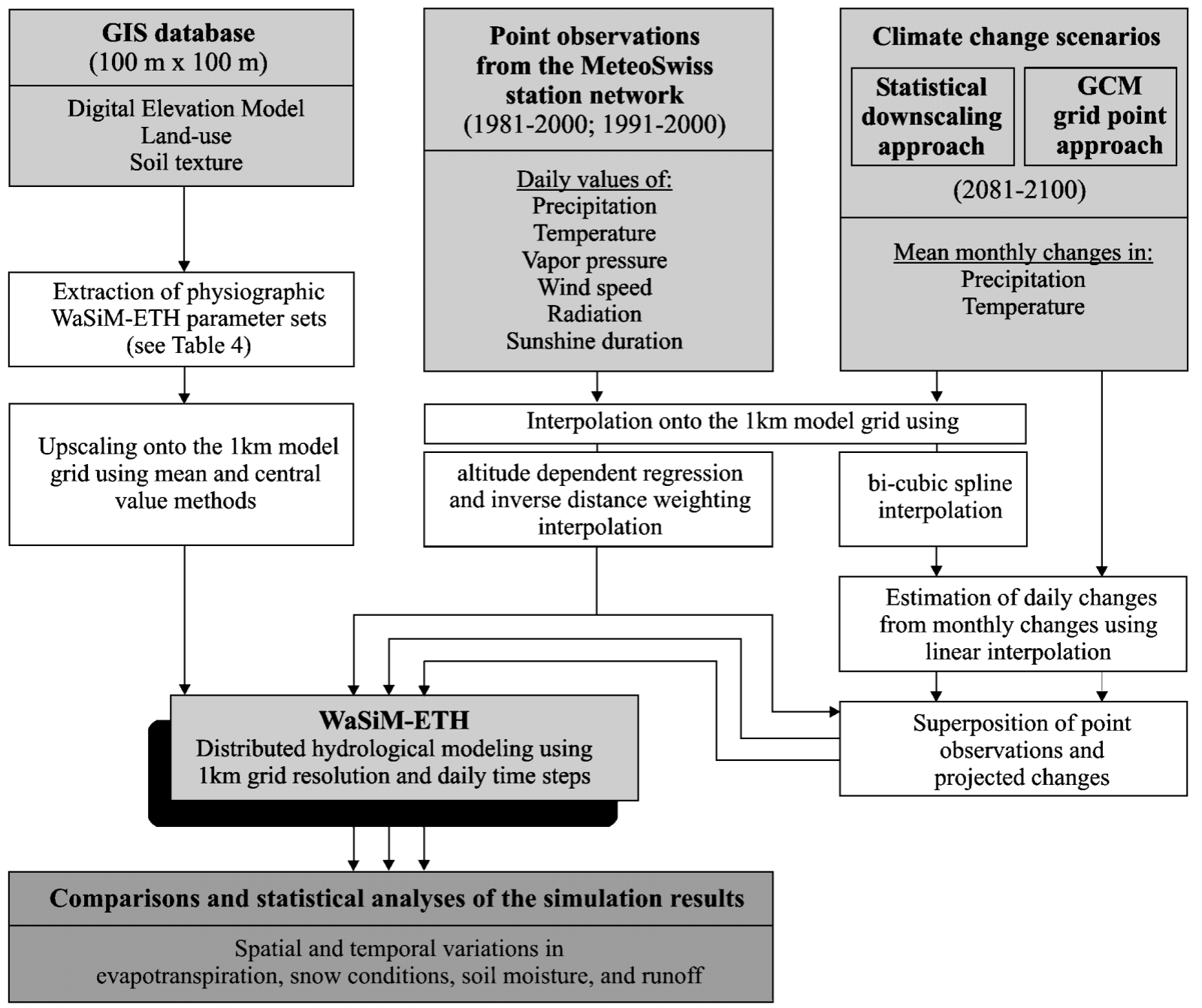

Fig. 3. Scheme of the experimental design

major soil textural groups. Note that, for reasons of data quality and computation time, the original $100 \mathrm{~m}$ grid resolution was subsequently reduced to a $1 \mathrm{~km}$ model resolution of the WaSiM-ETH applications.

\section{RESULTS}

\subsection{Temperature and precipitation scenarios}

The SD scenarios for the 2081-2100 time slice indicated seasonally varying deviations from the control run. As shown in Fig. 4 (left panels), changes in $T$ were projected to be positive throughout the year. For the Thur basin (Fig. 4a), the annual 17-scenario mean deviated from the control run by $+3.0^{\circ} \mathrm{C}$, while the range across the scenarios was between +1.7 and $+4.8^{\circ} \mathrm{C}$. Corresponding results were found for the Ticino basin (Fig. 4b). Here the annual increase in $T$ amounted to $+2.4^{\circ} \mathrm{C}$ (17-scenario mean), whereas the overall scenario set ranged from +1.3 to $+3.7^{\circ} \mathrm{C}$. In both basins, the largest $T$ anomalies occurred at the end of winter (February and March) and in late summer (August). For the Thur basin, the warming projected by the 17 -scenario mean was slightly higher for the winter period (December, January and February, referred to as DJF below) than for the summer period (June, July and August, referred to as JJA below) $\left(+3.3 \mathrm{vs}+3.1^{\circ} \mathrm{C}\right)$; for the Ticino basin, this ratio of winter to summer warming was somewhat different $\left(+2.1\right.$ vs $\left.+3.0^{\circ} \mathrm{C}\right)$. The range spanned by the 17 scenarios $^{1}$ was largest in January, February, May and August. It was smallest in April and October.

\footnotetext{
${ }^{1}$ The envelope representing the ensemble of scenarios in Figs. 4-9 is defined by the absolute minimum and maximum values at each date (either day or month). Thus, subsequent minima or maxima do not necessarily stem from the same scenario
} 
a

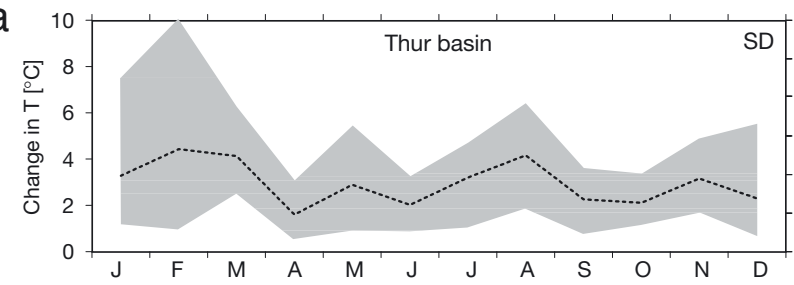

b

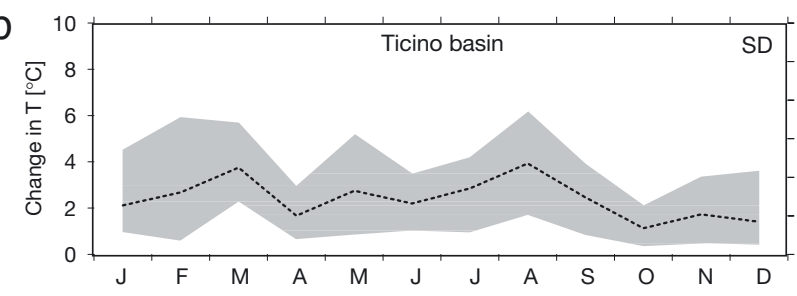

C

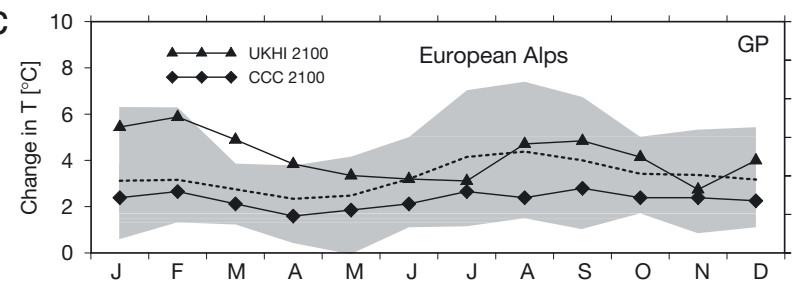

d

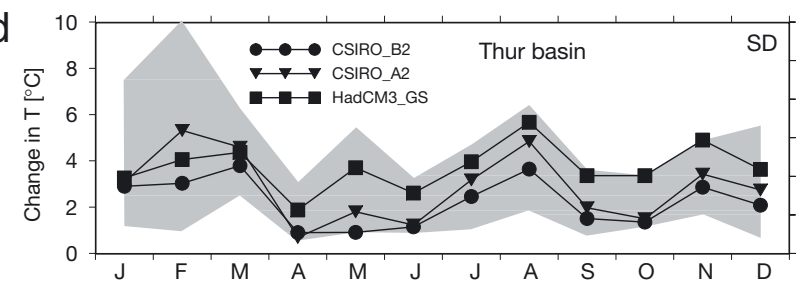

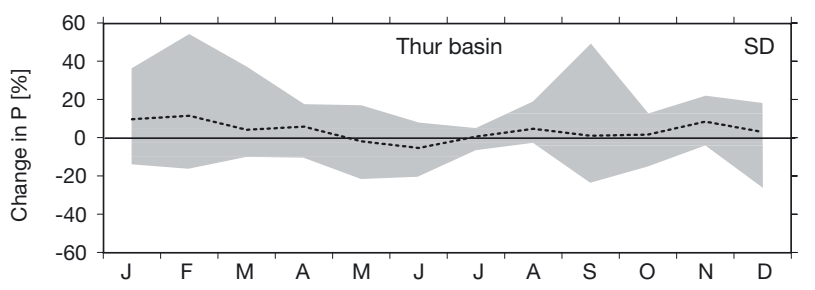
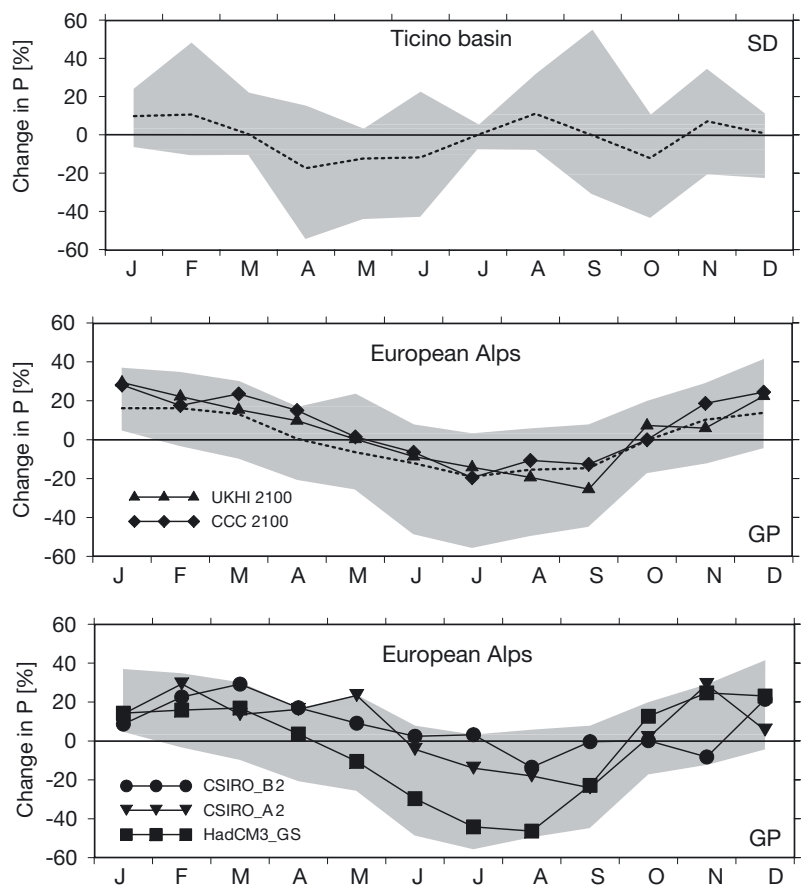

Fig. 4. Changes in monthly mean temperature $(T)$ and precipitation $(P)$ for the Thur and Ticino river basins as derived from a number of GCM simulations (Table 3) for 2081-2100. (a,b) Results of statistical downscaling (SD); (c) results from GCM grid points (GP). In addition, climate projections for 2100 of an earlier impact study (Schulla 1997) are displayed (GCM simulations carried out by the Hadley Centre [UKHI] and the Canadian Climate Center [CCC]). (d) Comparison of the $T$ and $P$ monthly projections for 'low' (CSIRO_B2), 'medium' (CSIRO_A2) and 'high' (HadCM3_GS) future climate warming. Dashed line: 17-scenario mean. Shaded area: 17-scenario range

This relatively high spread in the scenario changes for winter and summer $T$ was also found in the GP projections (Fig. 4c). In general, the seasonal pattern of the $T$ change (ensemble mean and range) was quite similar for the SD and GP scenario ensembles. However, the 17-scenario mean annual warming was somewhat stronger in the GP scenarios as compared with the $\mathrm{SD}$ scenarios and amounted to $+3.3^{\circ} \mathrm{C}$. Note that the changes in $T$ projected by the GP scenarios were not used for any hydrological simulations; they are shown here for comparison purposes only.

As opposed to $T$, projected changes in $P$ (Fig. 4, right panels) were either positive or negative, depending on scenario and season. The mean annual $P$ from the SD scenarios was found to increase by $37 \mathrm{~mm}$ in the Thur basin (Fig. 4a) and to decrease by $48 \mathrm{~mm}$ in the Ticino basin (Fig. 4b) (Table 5). In relative terms, these changes were small for both basins (less than $3 \%$ ). On the other hand, the scenario range was quite large and reflected a high degree of uncertainty in the projections. For the Thur basin the annual changes in $P$ ranged from $-72 \mathrm{~mm}(-5 \%)$ to $+160 \mathrm{~mm}(+11 \%)$, whereas for the Ticino basin the spread was from $-205 \mathrm{~mm}(-11 \%)$ to $+112 \mathrm{~mm}(+6 \%)$. Despite the large spread, the average over the scenario ensembles indicated a slight overall increase in winter (DJF) $P$ for both regions (slightly more than $+6 \%$ ), and a significant reduction for the Ticino basin during April to June (about $-13 \%$ on average). With respect to $P$, the GP scenarios (Fig. 4c) were more similar to each other than the SD scenarios, with a significant increase in winter $P$ and a marked decrease in summer $P$.

As noted in Section 1, the effects of climate change on the water cycle of the Thur basin have been studied already by Schulla (1997). Two sets of climate scenarios used in that study are displayed in Fig. 4c. 
The graphs indicate monthly changes in $T$ and $P$ by 2100. The changes were based on GCM scenario simulations of the Hadley Center (UKHI experiment) and the Canadian Climate Center (CCC experiment) carried out in 1989 (see Hulme et al. 1994). The 2 scenarios for $T$ are not congruent, but for most of the year they are both well within the range given by the present ensemble of GP scenarios. For precipitation, the UKHI and CCC scenarios agree with each other and with the ensemble mean of the present GCM GP projections.
In addition to the overall SD and GP projections (Fig. $4 \mathrm{a}-\mathrm{C}$ ), Fig. $4 \mathrm{~d}$ displays the $T$ and $P$ changes for a subset of climate scenarios: 'SDT-low', 'SDT-medium' and 'SDT-high' (Section 2.3). These scenarios were selected to investigate the hydrological effects of differently constructed $P$ scenarios (Section 3.6). It is worth noting the prominent decrease in summer GPP in the case of the HadCM3_GS scenario (Fig. 4d, right panel).

Unless otherwise specified, all hydrological model results presented in the following sections were based on ensemble simulations using the SD scenarios (SDT_SDP).
Table 5. Projected absolute values and relative (in \% of the control run changes in annual totals for precipitation $(P)$, evapotranspiration $(E T)$, and runoff $(R)$ for the Thur and Ticino basins. Projection results (2081-2100) based on the use of 17 different climate-change scenarios obtained by statistical downscaling

\begin{tabular}{|c|c|c|c|c|c|c|}
\hline & $\begin{array}{c}P \\
(\mathrm{~mm})\end{array}$ & $\begin{array}{l}\Delta P \\
(\%)\end{array}$ & $\begin{array}{c}\text { ET } \\
(\mathrm{mm})\end{array}$ & $\begin{array}{l}\Delta \mathrm{ET} \\
(\%)\end{array}$ & $\begin{array}{c}R \\
(\mathrm{~mm})\end{array}$ & $\begin{array}{l}\Delta R \\
(\%)\end{array}$ \\
\hline \multicolumn{7}{|l|}{ Thur basin } \\
\hline \multicolumn{7}{|l|}{ Control run (1981-2000) } \\
\hline Long-term mean & 1471 & & 618 & & 861 & \\
\hline \multicolumn{7}{|l|}{ Scenarios (2081-2100) } \\
\hline 17-scenario mean & 1508 & +2.5 & 719 & +16.2 & 806 & -6.4 \\
\hline 17-scenario minimum & 1399 & -4.9 & 674 & +9.0 & 718 & -16.6 \\
\hline 17-scenario maximum & 1631 & +10.9 & 765 & +23.6 & 917 & +6.5 \\
\hline \multicolumn{7}{|l|}{ Ticino basin } \\
\hline \multicolumn{7}{|l|}{ Control run (1991-2000) } \\
\hline Long-term mean & 1822 & & 546 & & 1250 & \\
\hline \multicolumn{7}{|l|}{ Scenarios (2081-2100) } \\
\hline 17-scenario mean & 1774 & -2.6 & 637 & +16.7 & 1118 & -10.5 \\
\hline 17-scenario minimum & 1617 & -11.2 & 594 & +8.8 & 975 & -22.0 \\
\hline 17-scenario maximum & 1934 & +6.2 & 674 & +23.4 & 1295 & +3.6 \\
\hline
\end{tabular}

\subsection{Evapotranspiration and soil water content}

As shown in Fig. 5, ET was found to increase significantly in all experiments and for both regions. The 17-scenario mean showed an increase in the annual ET rate of about $16 \%$ relative to the control runs (Table 5). Changes in ET were calculated to be smaller than the corresponding changes in $\mathrm{PET}$, for which an increase between $20 \%$ (Thur basin) and $24 \%$ (Ticino basin) was obtained (not shown). As a result, the wetness index ET/PET showed significantly lower values in the projection time slice than in the control run (Fig. 6, upper panels). This is particular true for the summer period (JJA), for which the 17-scenario mean indicated a decrease in ET/PET of
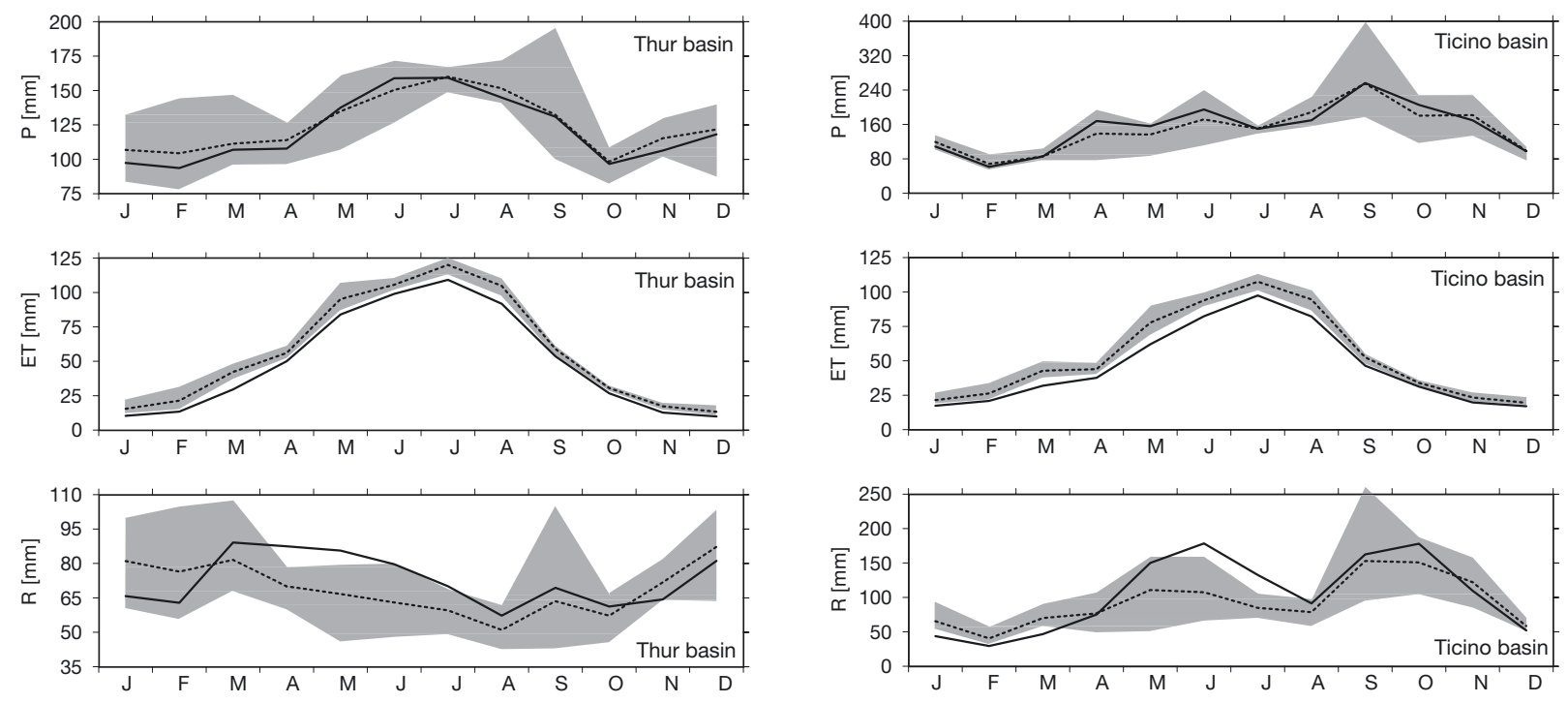

Fig. 5. Mean monthly values of precipitation $(P)$, evapotranspiration $(E T)$ and runoff $(R)$ for the Thur and Ticino basins. Data are results of the control runs (solid lines) and of the 2081-2100 projections displaying 17-scenario mean (dashed lines) and range (shaded areas) 

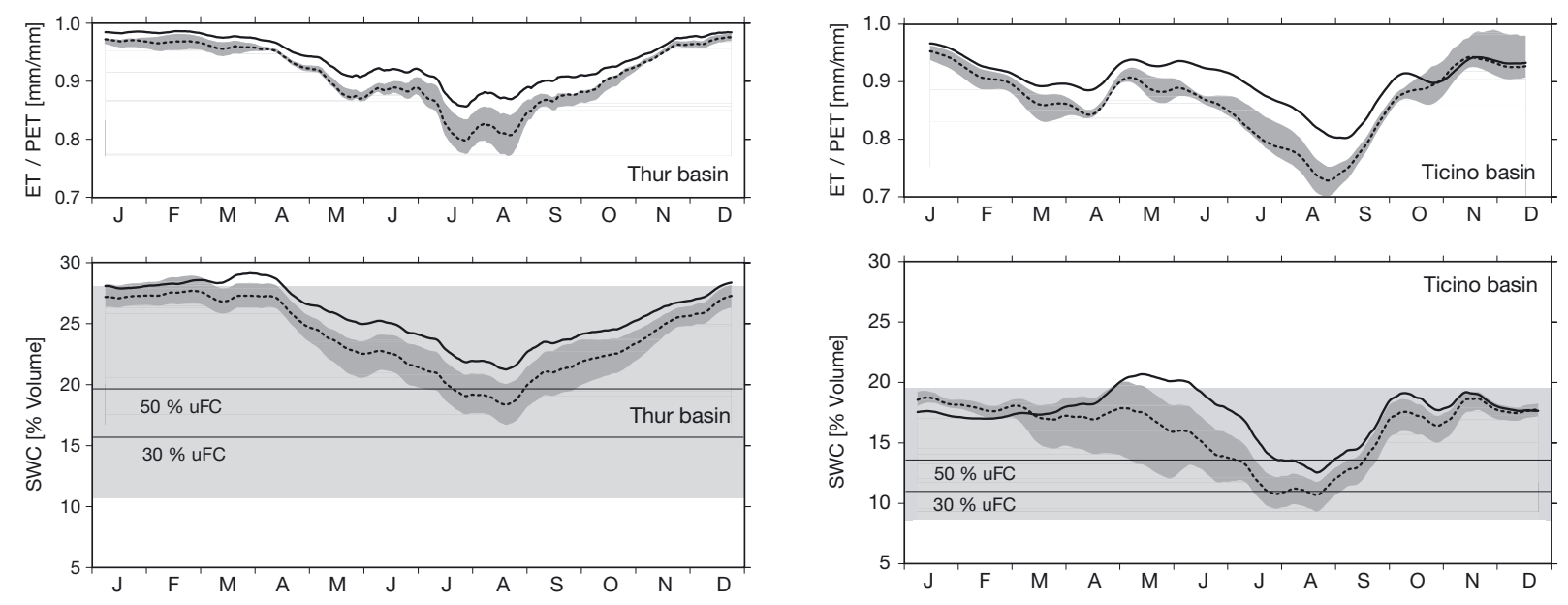

Fig. 6. Mean $15 \mathrm{~d}$ average of wetness index (ET/PET = ratio of actual to potential evapotranspiration) and soil-water content (SWC) in the rooting zone for the Thur and Ticino basins. uFC: usable field capacity. Data displayed as in Fig. 5

about $5 \%$ (Thur basin) and $8 \%$ (Ticino basin) on the average.

Like the future evolution of ET/PET, the projections of SWC indicated decreasing values for both basins over most of the year, in particular during the vegetation period (Fig. 6, lower panels). The relative reduction in SWC was 7.2\% (Thur basin) and 7.7\% (Ticino basin) on a yearly average, and $9.7 \%$ (Thur basin) and $16.2 \%$ (Ticino basin) when averaged over the vegetation period from April to August. It is worth noting the large projection range in SWC in the Ticino basin during spring and early summer. In this case the model projections for the different scenarios diverged significantly, both in magnitude and timing.

In addition to considering absolute changes in SWC, it is interesting to analyze the occurrence and persistence of dry spells. To this aim, 2 thresholds of SWC were considered: 30 and $50 \%$ of the plant-usable field capacity (uFC). As shown in Fig. 6, the mean number of days with SWC smaller than $50 \%$ uFC significantly increased in 2081-2100 as compared with the reference period, from 0 to $32 \mathrm{~d}$ for the Thur basin and from 29 to $75 \mathrm{~d}$ for the Ticino basin.

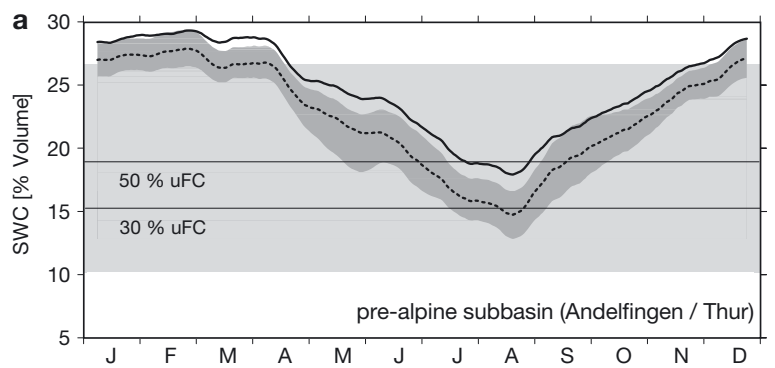

In all cases, SWC was lowest in August even in the control simulation. At this time, the 17-scenario mean of SWC was slightly above $30 \% \mathrm{uFC}$ in the Thur basin and close to $30 \%$ uFC in the Ticino basin. Values of SWC well below this threshold were computed for the lower located parts of both basins (Fig. 7a). Compared with this, the depletion of SWC was smaller for alpine or high-alpine subareas (Fig. 7b).

\subsection{Snow cover and snow-water equivalent}

As seen in Fig. 8, climate change would have severe effects on the future snow conditions (spatial extent, duration and volume of snow cover) in alpine terrain. For the Thur and Ticino basins, the 17 -scenario projections revealed a decrease in the annual mean snowwater equivalent (SWE) between $73 \%$ (Thur basin) and $69 \%$ (Ticino basin) as compared with the control run. In absolute terms, these negative changes were more pronounced for the Ticino basin than for the Thur basin (57 vs $14 \mathrm{~mm}$ ). Averaged over the winter period (DJF), SWE was calculated to diminish by $68 \%$

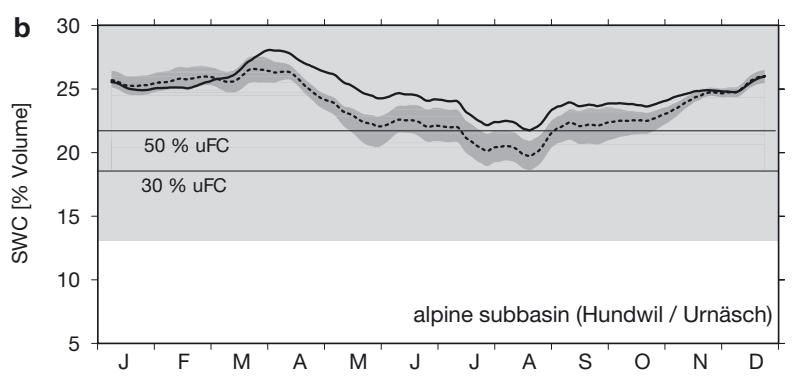

Fig. 7. Mean $15 \mathrm{~d}$ average of soil-water content (SWC) for (a) lower (stream gauge Andelfingen, $105 \mathrm{~km}^{2}$, mean altitude $436 \mathrm{~m}$ a.s.l.) and (b) higher (stream gauge Hundwil, $61 \mathrm{~km}^{2}$, mean altitude $1110 \mathrm{~m}$ a.s.l.) Thur subbasins. uFC: usable field capacity. Data displayed as in Fig. 5 

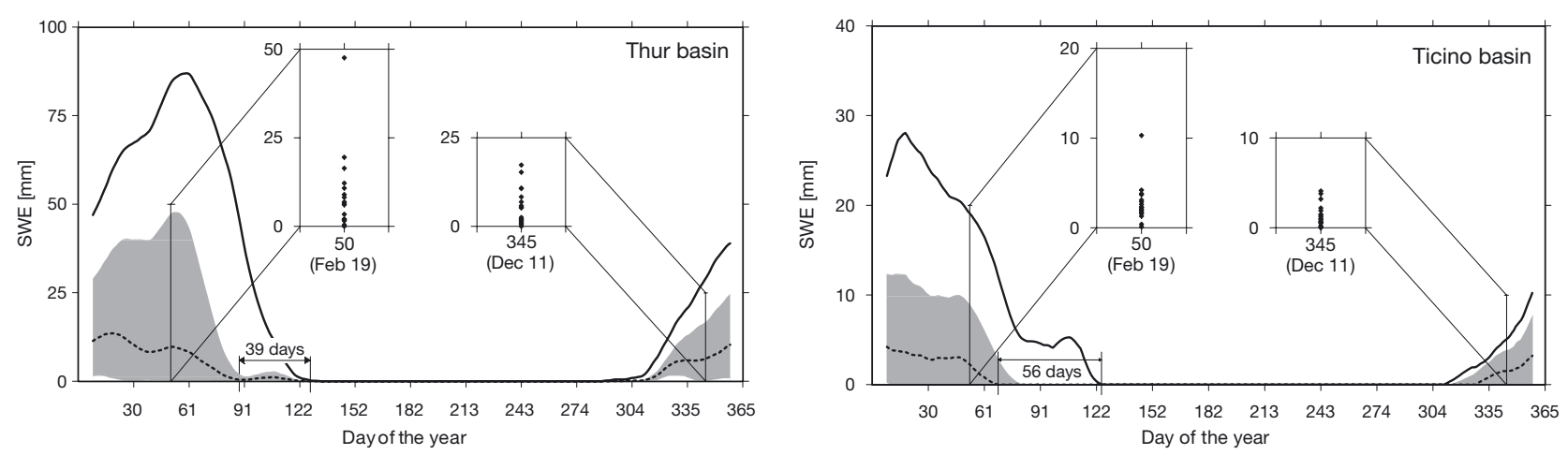

Fig. 8. Mean $15 \mathrm{~d}$ average of snow-water equivalent (SWE) for the Thur and Ticino basins at 1000 m a.s.l. Data displayed as in Fig. 5

(26 $\mathrm{mm})$ in the Thur basin and by $57 \%(66 \mathrm{~mm})$ in the Ticino basin. The lifetime of continuous snow cover was shortened by about 1 to 3 mo, while the snow-line was raised by some 300 to $600 \mathrm{~m}$. The occurrence of snow-free conditions (SWE $<1 \mathrm{~mm}$ ) was advanced by about 5 to $8 \mathrm{wk}$ in spring, as opposed to a postponement of only about 1 to $3 \mathrm{wk}$ for the begin of the snow season. This asymmetry appeared as a consequence of the temporal distribution of changes in temperature, with a larger increase expected at the beginning than at the end of the year (Fig. 4).

In both basins, large differences across the scenario members occurred in particular during the spring season. However, the location of the ensemble mean and the distribution of the 17 projections at a particular date revealed that also at this time the bulk of the scenarios was in a relatively narrow range. As seen in Fig. 8, only 1 scenario (HadCM3_B2, see Table 3) projected larger SWE values.

\subsection{Runoff}

In response to changes in $P, \mathrm{ET}, \mathrm{SWC}$ and $\mathrm{SWE}$, major differences between the 2 time slices (reference and scenario) were also found with respect to runoff (Fig. 5). In our experiment, winter (DJF) runoff increased on average by $14 \%$ (Thur basin) and $31 \%$ (Ticino basin), whereas summer (JJA) runoff reduced by $16 \%$ (Thur basin) and $33 \%$ (Ticino basin). The

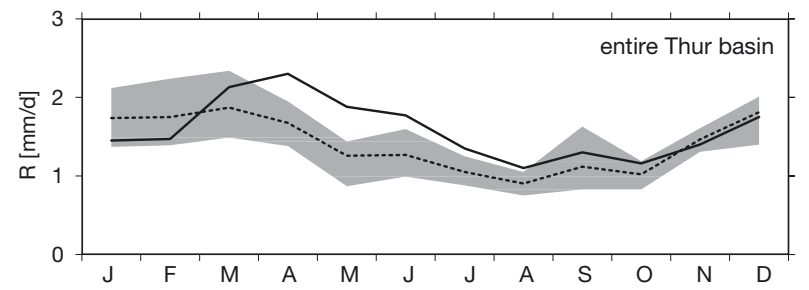

annual mean runoff was reduced by about $6 \%$ (Thur basin) and $10 \%$ (Ticino basin) relatively to the control run. Note that, depending on the selected scenario, the projection results differed strongly; for the annual mean runoff, the changes were between -17 and $+7 \%$ for the Thur basin and between -22 and $+4 \%$ for the Ticino basin.

In general, significant changes in runoff were projected in spring (early summer), mainly due to clearly changed snow conditions (see Section 3.3). As a consequence, the projected runoff peaks occurred earlier and substantially reduced relative to the peaks in the control runs.

Note, furthermore, that changes in runoff were largest for areas where runoff is most strongly controlled by snow dynamics. This can be shown by comparing the runoff hydrographs of the entire (more prealpine) Thur basin with that of one of its alpine subbasins (Fig. 9). For the Thur basin, the runoff peak was reduced by about $20 \%$ and was shifted by about 1 mo. Compared with this, the 17-scenario mean for the alpine subbasin showed a substantially stronger peak reduction (around 50\%) and a larger phase shift (about 2 mo) as well.

\subsection{Effects of different emission scenarios}

The ensemble of climate scenarios used in our study (Table 3) opened the possibility to analyze effects of

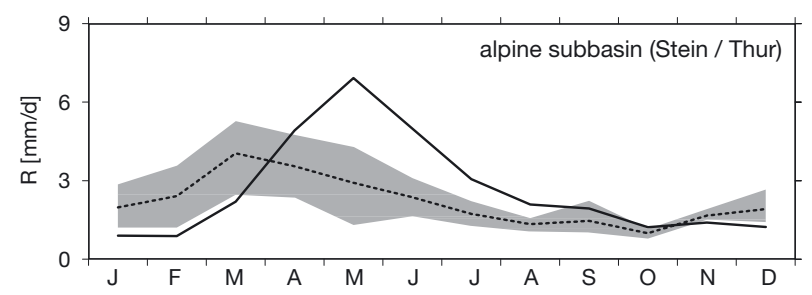

Fig. 9. Monthly values of mean daily runoff for the entire Thur basin (stream gauge Andelfingen, $1700 \mathrm{~km}^{2}$, mean altitude $769 \mathrm{~m}$ a.s.l.) and for one of its alpine subbasins (stream gauge Stein, $84 \mathrm{~km}^{2}$, mean altitude $1448 \mathrm{~m}$ a.s.l.). Data displayed as in Fig. 5 
emission scenarios separately (Table 6). For the Thur basin, the SD scenarios based upon the IS92a emission scenarios showed largest increases in $P$, in particular during the winter period (DJF) (about $+10 \%$ ). In comparison, significantly smaller changes were projected by the SD scenarios based on the A2 and B2 emission scenarios. For the Ticino basin, the emission scenarios GG and A2 showed the most pronounced changes in $P$ of about $-4 \%$ on an annual basis. Compared with this, a slight increase in $P$ of about $1 \%$ was projected in the case of the B2 scenario group.

Changes in $T$ (not shown in Table 6) were consistently positive for all emission scenarios and for both basins. The annual mean values of changes were between $+1.5^{\circ} \mathrm{C}(\mathrm{B} 2$, Ticino basin) and $+3.6^{\circ} \mathrm{C}$ (GG, Thur basin). In general, the lowest warming was indicated by the climate projections using the B2 emission scenario. As a consequence, the B2 projections showed the smallest changes in ET, SWE and SWC. For example, the increase in annual ET was about $11 \%$ for the B2 driven
Table 6. Projected relative (in \% of the control run) changes in annual totals for precipitation $(P)$, evapotranspiration $(\mathrm{ET})$ and runoff $(R)$ for the Thur and Ticino basins according to the statistical-downscaling (SD) scenarios. Projection results refer to 2081-2100 and are mean changes obtained for each group of emission scenarios: GG, GS, A2, and B2 (see Table 3). DJF: December-February; JJA: June-August

\begin{tabular}{|c|c|c|c|c|c|c|c|c|}
\hline \multirow[b]{2}{*}{ Scenario } & \multicolumn{4}{|c|}{ Thur basin $\longrightarrow$} & \multicolumn{4}{|c|}{ - Ticino basin -} \\
\hline & GG & GS & A2 & B2 & GG & GS & A2 & B2 \\
\hline \multicolumn{9}{|l|}{$\Delta \boldsymbol{P}(\%)$} \\
\hline Winter (DJF) & +10.6 & +8.9 & +1.8 & +3.3 & +12.2 & +4.9 & +2.1 & +6.2 \\
\hline Summer (JJA) & -0.8 & -0.6 & -1.6 & +1.7 & -1.4 & -1.7 & -3.3 & +2.2 \\
\hline Year & +3.2 & +4.3 & +0.5 & +1.8 & -4.3 & -2.4 & -4.5 & +1.0 \\
\hline \multicolumn{9}{|l|}{$\Delta \mathbf{E T}(\%)$} \\
\hline Winter (DJF) & +89.4 & +82.5 & +75.4 & +53.9 & +25.8 & +24.5 & +21.9 & +12.8 \\
\hline Summer (JJA) & +12.1 & +11.6 & +11.3 & +7.6 & +14.0 & +13.5 & +14.1 & +9.9 \\
\hline Year & +19.4 & +17.7 & +15.9 & +11.0 & +19.4 & +18.2 & +16.9 & +11.7 \\
\hline \multicolumn{9}{|l|}{$\Delta \boldsymbol{R}(\%)$} \\
\hline Winter (DJF) & +21.6 & +15.2 & +7.9 & +10.0 & +39.3 & +32.2 & +28.1 & +22.9 \\
\hline Summer (JJA) & -19.1 & -17.1 & -18.1 & -8.9 & -37.5 & -35.9 & -35.8 & -20.4 \\
\hline Year & -5.9 & -5.0 & -10.3 & -4.5 & -13.5 & -10.8 & -13.4 & -3.5 \\
\hline
\end{tabular}
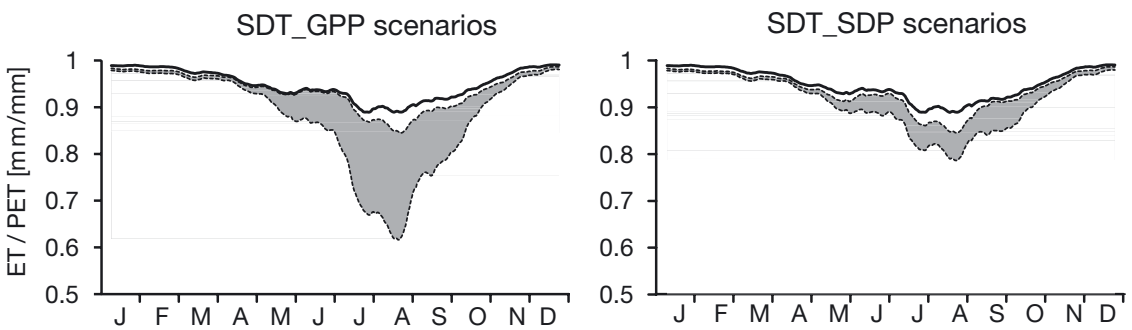

scenarios and $16-19 \%$ for the other scenario experiments. Comparable results were found for the SWE and SWC projections. If using the B2 scenarios, the annual mean SWE was reduced by about $60 \%$ (Thur basin) and $54 \%$ (Ticino basin), respectively. In all other
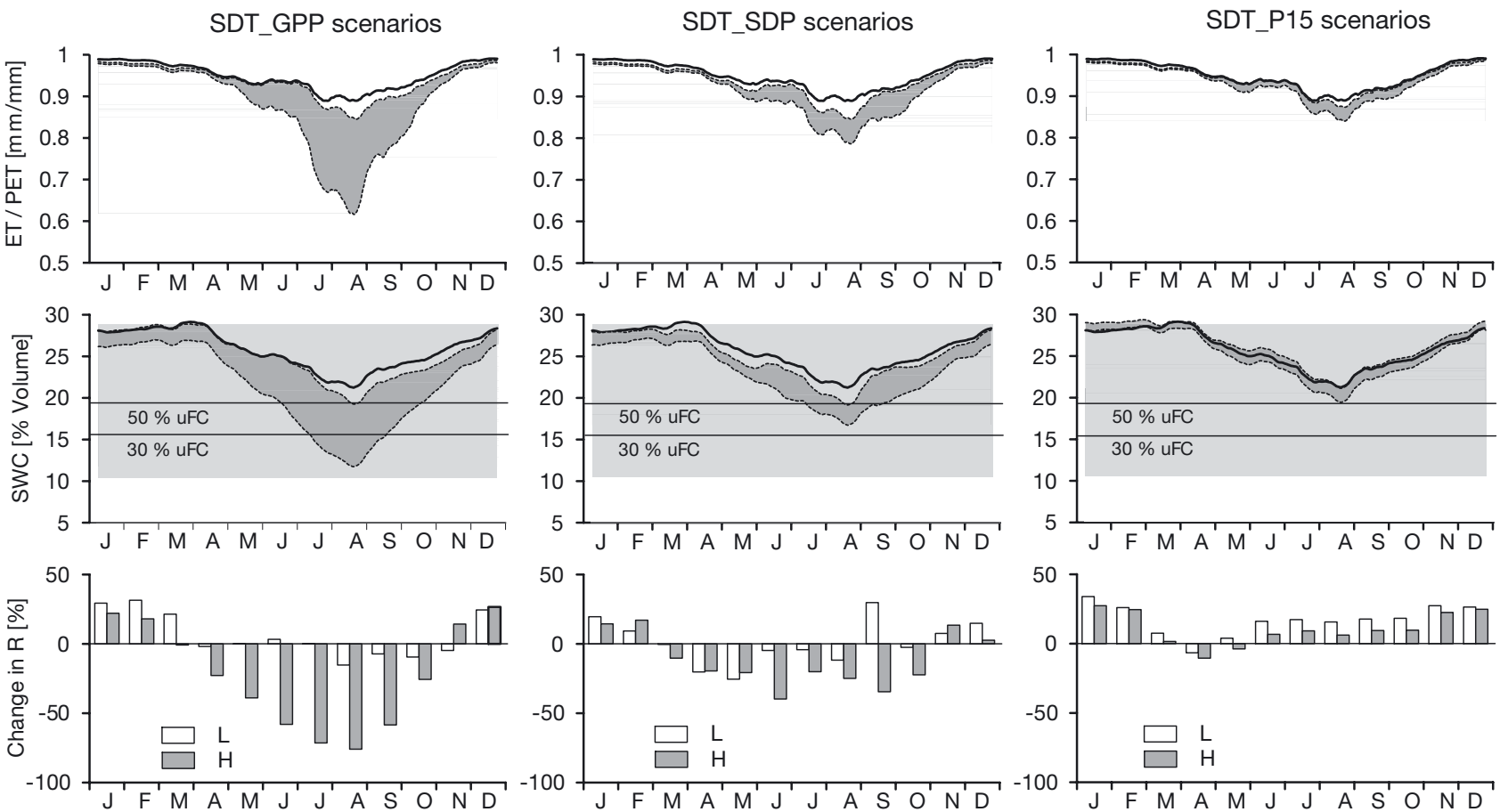

Fig. 10. Changes in monthly mean precipitation $(P)$ and runoff $(R)$, and mean $15 \mathrm{~d}$ average of wetness index (ET/PET) and soilwater content (SWC) for the Thur basin. Data are results of the control runs (solid lines) and of the 2081-2100 projections obtained by using 2 climate scenarios representing future warming of 'low' (L) and 'high' $(\mathrm{H})$ magnitude. The projections are based on differently constructed climate scenarios (from left to right): a combination of statistically downscaled temperatures (SDT) and GCM grid-point scenario for $P(\mathrm{GPP}) ;$ SDT and statistically downscaled precipitation (SDP); and SDT and uniform $15 \%$ increase in $P$ (P15). For details, see Section 2.3. uFC: usable field capacity 
cases, this reduction was significantly higher: 77-79\% (Thur basin) and 71-77\% (Ticino basin). With respect to SWC, the B2 projection showed moderately decreased soil-moisture values of about $7 \%$ (Thur basin) and $13 \%$ (Ticino basin) for the summer period (JJA). In comparison, this decrease was much stronger pronounced in the hydrological projections of the remaining scenarios. Here the summer reduction in SWC was $12-14 \%$ for the Thur basin and $21-24 \%$ for the Ticino basin.

In addition, the effects of different emission scenarios became obvious for runoff projections. As shown in Table 6, the most significant changes in the annual mean runoff were projected by the A2 (Thur basin) and GG (Ticino basin) scenarios (reductions between 10 and $13 \%$ ), whereas a less-reduced runoff of about $4 \%$ occurred for the B2 projections.

\subsection{Hydrological response to additional precipitation scenarios}

The results displayed in Figs. 10 \& 11 clearly indicate that the use of scenarios for $P$ more extreme than those included in the SD scenario set would significantly modify the water-balance changes found in the SDscenario-driven experiments. The projection results for the SDT_GPP scenarios tended to intensify the hydrological changes derived from the SD scenarios. This was especially true in the case of the selected 'SDThigh' scenario (HadCM3_GS). Here, the strong decrease in summer $P$ led to a pronounced summer dryness with very low values of soil moisture and runoff. Compared with this, the hydrological changes obtained for the 'SDT-low' scenario (CSIRO_B2) were quite similar for both the SDT_GPP and SDT_SDP scenario sets.

With respect to the wetness-index ET/PET and soil moisture (Fig. 10), smallest changes were projected when using the SDT_P15 climate scenarios to drive the hydrological simulation. In this case, the uniform allseason increase in $P(+15 \%)$ almost compensates the potential T-induced decrease in ET/PET and SWC. It is also worth mentioning that both scenarios - 'SDT-low' and 'SDT-high' - projected changes of similar magnitude. As opposed to the results of the SDT_GPP and SDT_SDP scenarios, the SDT_P15-driven projections showed positive runoff changes not only for winter
Fig. 11. Projected relative (in \% of the control run) changes in precipitation $(P)$, evapotranspiration (ET) and runoff $(R)$ for the Thur basin. Projection results (2081-2100) based on the usage of 3 different groups of climate scenarios representing 'low' (L), 'medium' (M), and 'high' (H) future warming. Each scenario group presents results referring to 3 different scenario constructions, as explained in Fig. 10. DJF: December-February; JJA: June-August
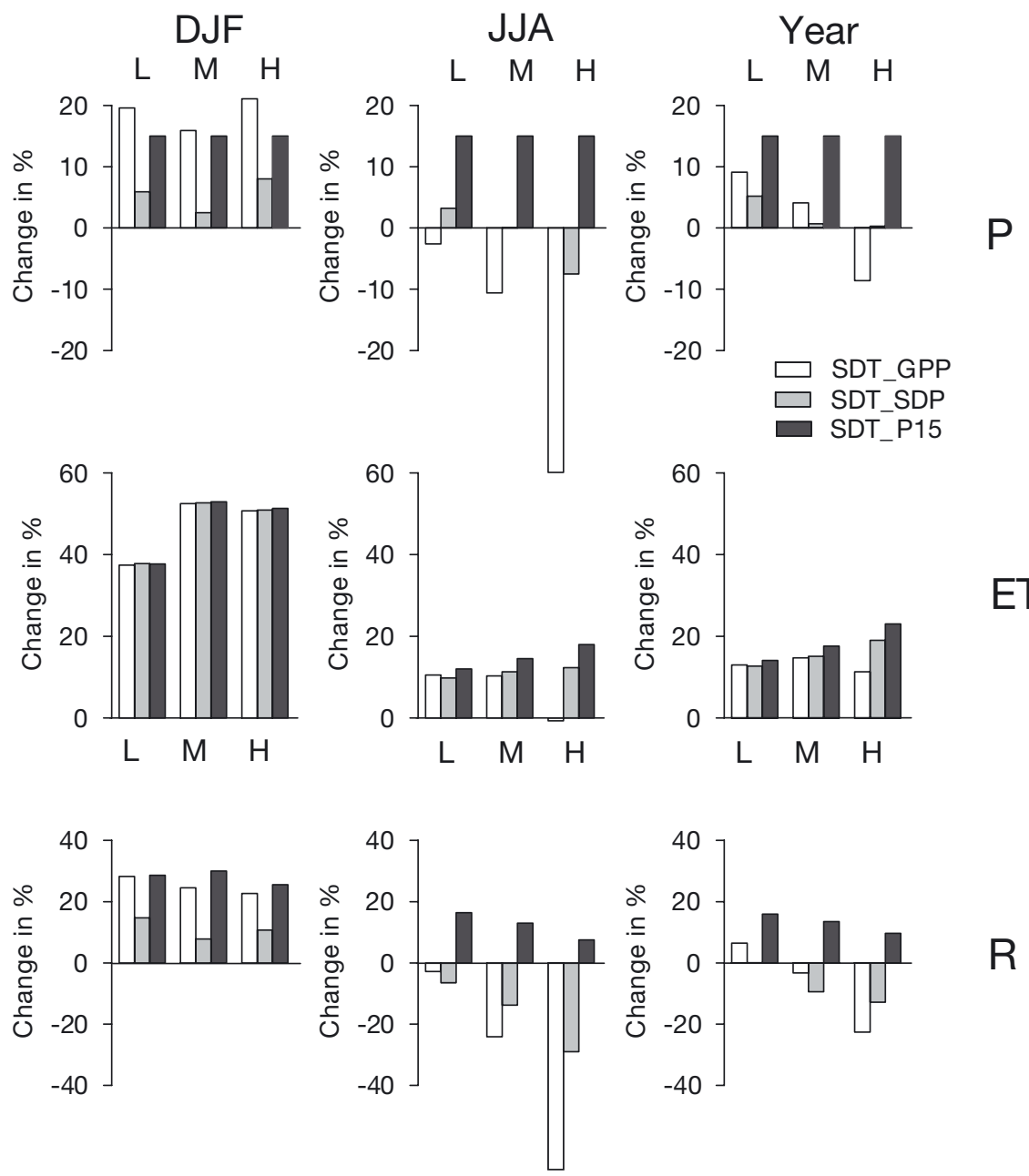
but also for summer, independently of the choice of scenario.

Fig. 11 displays the seasonal and annual waterbalance changes for the 'SDT-low', 'SDT-medium' and 'SDT-high' subset of climate-change scenarios and for 3 different scenario construction techniques for $P$ (GPP, SDP, P15). For the winter period (DJF), all projections agreed with respect to the sign of the change, and SDT_GPP and SDT_P15 also agreed with respect to the magnitude of the change. However, for the summer season (JJA) the $P$ scenarios differed substantially, resulting in different projections for runoff. While the GPP and SDP scenarios resulted in a negative runoff change, the opposite was found in the case of the P15 scenarios. Changes in the runoff regime during JJA determined the corresponding changes in the annual mean.

For the summer season, ET projections agreed with each other except the SDT-high, GPP scenario. In this latter case, the very large decrease in $P$ and SWC and its limiting effects on ET was responsible for a negative change in ET.

\section{DISCUSSION AND CONCLUDING REMARKS}

Our investigation of the possible impact of climate change on the water cycle of 2 alpine river basins revealed the potential for dramatic changes. The results suggest an increase in $\mathrm{ET}_{\text {; }}$ a substantial reduction in the extent and duration of snow cover; a strong tendency toward summertime depletion of soil moisture; and a shift in the seasonal pattern of runoff, with earlier and reduced peaks due to snowmelt.

As mentioned at the beginning of this paper, the effects of climate change on the hydrological regime of mountainous river basins in the mid-latitudes have been investigated already in earlier studies (e.g. Gurtz et al. 1997, Schulla 1997, Hamlet \& Lettenmaier 1999, Leung \& Wigmosta 1999, Hamlet et al. 2001, Menzel \& Bürger 2002, Snover et al. 2003), with results that agree in a broad sense with the present findings (see also Table 7). This provides some confidence that the main outcomes are robust. A note of caution is nevertheless necessary.

First of all, our simulations included major simplifications that were dictated by technical reasons. For instance, climate scenarios only considered changes in the monthly mean values of $T$ and $P_{\text {, }}$ but did not take into account corresponding changes in other meteorologi- cal variables, such as wind speed, radiation and relative humidity (RH). Considering RH to be not affected by climate change is a common assumption (see e.g. Seneviratne et al. 2002). However, results of GCM simulations for a $2 \times \mathrm{CO}_{2}$ scenario indicate a possible decrease in summer RH in the order of $10-15 \%$ for the Alpine region (Wild et al. 1996). This would imply an increase in summer PET, but whether and to what extent this would further affect ET very much depends on the specific choice of the $P$ and $T$ scenarios (cf. Fig. 11).

Second, our scenarios did not take into account possible shifts in the occurrence and intensity of extreme events, because the derivation of such a set of regional climate scenarios was beyond our means. Future work should address this issue. In this context, we refer to the findings of Schär et al. (2004), who postulated that, in the Alpine region, global warming will lead to a change in the distribution of $T$, resulting in a more frequent occurrence

of heat waves comparable to the one that affected the European continent in the summer of 2003.

Third, our simulations assumed a static description of the vegetation, with prescribed phenology and developmental stages. This is a serious limitation, because they neglect the feedbacks between the biosphere and the atmosphere, including those related to the composition of plant societies (Fischlin \& Gyalistras 1997, Dale et al. 2000, Keller et al. 2002). Our results, in particular those regarding ET and SWC, must therefore be seen as a first guess.

As opposed to the earlier investigations mentioned above, the present analysis was based on a much wider set of climate scenarios. This allows for a few considera-

Table 7. Projected relative (in \% of the control run) changes in precipitation $(P)$, evapotranspiration (ET) and runoff $(R)$ as obtained by earlier impact studies for the Thur and Ticino basins. Projection results refer to 2100. na: not assessed

\begin{tabular}{|c|c|c|c|c|}
\hline $\begin{array}{l}\text { Number of IPCC scenarios } \\
\text { Hydrological model used } \\
\text { Control period }\end{array}$ & $\begin{array}{r}\text { Gurtz } \\
\quad(19 \\
\text { HBVE } \\
1993\end{array}$ & $\begin{array}{l}\text { z et al. } \\
997) \\
3 \\
\text { VATH }^{\mathrm{a}} \\
-1994\end{array}$ & $\begin{array}{c}\text { Schulla } \\
(1997) \\
2 \\
\text { WaSiM-ETH }^{\mathrm{b}} \\
\text { 1981-1995 }\end{array}$ & $\begin{array}{c}\text { Schaper \& Seidel } \\
(2001) \\
1 \\
\text { SRM+G } \\
1983-1994^{\mathrm{d}}\end{array}$ \\
\hline $\begin{array}{l}\text { Thur basin } \\
\Delta P(\%) \\
\Delta \mathrm{ET}(\%) \\
\Delta R(\%)\end{array}$ & $\begin{array}{c}\text { Min } \\
-6.0 \\
+7.7 \\
-18.0\end{array}$ & $\begin{array}{c}\text { Max } \\
+0.2 \\
+36.0 \\
-13.0\end{array}$ & $\begin{array}{cc}\text { Min } & \text { Max } \\
+0.3 & +2.9 \\
+5.9 & +34.0 \\
-19.0 & +1.2\end{array}$ & $n a^{e}$ \\
\hline $\begin{array}{l}\text { Ticino basin } \\
\Delta P(\%)\end{array}$ & & иа & na & $+10.0^{\mathrm{e}}$ \\
\hline $\begin{array}{l}\Delta R(\%) \\
{ }^{\mathrm{a}} \text { Extended version of the cl } \\
\text { b Topmodel version of the } \mathrm{C} \\
{ }^{\mathrm{c}} \text { Snowmelt runoff model }(\mathrm{S} \\
{ }^{\mathrm{d}} \text { Runoff simulation for selec } \\
{ }^{\mathrm{e}} \text { Change in winter } P \text { only; } \mathrm{s}\end{array}$ & $\begin{array}{l}n \\
\text { assical I } \\
\text { VaSiM-E } \\
\text { RM) wit } \\
\text { cted yea } \\
\text { ummer }\end{array}$ & $\begin{array}{l}\text { la } \\
\text { HBV mo } \\
\text { ETH mo } \\
\text { th exten } \\
\text { irs withi } \\
P \text { was a }\end{array}$ & $\begin{array}{l}\text { na } \\
\text { el (Bergström } 1 \\
\text { el } \\
\text { on for Glacierm } \\
\text { this period } \\
\text { sumed to remai }\end{array}$ & $\begin{array}{l}-6.3 \\
\text { 1995) } \\
\text { melt }(\mathrm{G}) \text { modelling } \\
\text { in unchanged }\end{array}$ \\
\hline
\end{tabular}


tions concerning the uncertainty of the results (given the basic limitations just discussed). In general, most coherent conclusions could be drawn for variables closely correlated to $T$ (ET and SWE), whereas a significantly greater spread was found for variables largely dominated by changes in $P$, in particular runoff. This, of course, reflects uncertainties in the $P$ scenarios. A quantitative analysis of the $P$ scenarios suggests that large uncertainties are introduced by the choice of GCM and regionalization procedure. In this context, the question remains as to whether global $P$ scenarios should be preferred to their regional counterparts obtained by SD. For the time being, 2 arguments support the use of SD scenarios. First, GCM simulations tend to underestimate summer $P$ in the Mediterranean/Alpine area (Schär et al. 1999), and this tendency is enhanced under greenhouse-gas forcing (Giorgi \& Mearns 2002). Consequently, risks of enhanced drying might be possibly smaller than suggested by many GCM scenario studies (see also Gyalistras 2000). Second, SD procedures are characterized by a relatively high robustness in reproducing selected characteristics of the $P$ distribution (Trigo \& Palutikof 2001).

The choice of emission scenarios also has an appreciable impact on the $T$ and $P$ scenarios. Quite generally, the IS92 scenarios (GG and GS) are characterized by larger warming and more substantial changes in $P$ than the SRES scenarios. Furthermore, the smallest changes were projected by the B2 family. This is not surprising, as the B2 scenarios assume a more environmentally friendly development of the global economy. However, our simulations showed that also the B2 emission scenarios would lead to significant changes in the hydrology of the river basins considered. For example, snow resources would be reduced by $74 \%$ in 2100 as compared with today. This is on the same order of magnitude as the reduction by $90 \%$ projected by the A2 family.

Despite all limitations and uncertainties, our analysis was able to show the importance of the physiographic characteristics, such as topography and land-use (Bronstert et al. 2002), for the assessment of the impact of climate change on the hydrological regime of mountainous river basins. For example, the larger proportion of high elevations in the Ticino basin was responsible for the fact that changes in runoff dynamics were more largely controlled by the shift in the snow conditions.

In conclusion, despite significant improvements as compared with previous investigations, our analysis cannot be considered as final. For improving the present results, priority should be given to a better quantification of the reliability of the climate scenarios, for instance, along the lines explored by Wigley \& Raper (2001), and at least a partial integration of vegetation dynamics into our hydrological model.
Acknowledgements. We would like to thank the IPCC for making available the data of GCM scenarios (http://ipccddc.cru.uea.ac.uk). In addition, we thank MeteoSwiss, the Swiss National Hydrological Survey, and the Swiss Federal Statistical Office for providing meteorological and hydrological measuring data and topographic data. Useful comments and suggestions from 2 anonymous reviewers are also gratefully acknowledged. Financial support for this study was provided by the Swiss National Science Foundation in the framework of the NCCR Climate Programme. Research by D.G. was supported by the Swiss Federal Research Station for Agroecology and Agriculture (FAL, project CS-MAPS) and the Swiss Agency for the Environment, Forests and Landscape (BUWAL, project No. 2001.L.03 / TREWALP).

\section{LITERATURE CITED}

Bergström S (1995) The HBV model. In: Singh VP (ed) Computer models of watershed hydrology. Water Resources Publications, Littleton, CO, p 443-476

Braun LN (1985) Simulation of snowmelt runoff in lowland and lower alpine regions of Switzerland. Zürcher Geographische Schriften 21, Swiss Federal Institute of Technology (ETH), Zürich

Bronstert A, Niehoff D, Bürger G (2002) Effects of climate and land-use change on storm runoff generation: present knowledge and modelling capabilities. Hydrol Process 16:509-529

Carsel ILF, Parrish RS (1988) Developing joint probability, distributions of soil water retention characteristics. Water Resour Res 24(5):755-769

Charles SP, Bates BC, Whetton PH, Hughes JP (1999) Validation of downscaling models for changed climate conditions: case study of southwestern Australia. Clim Res 12(1):1-14

Dale VH, Joyce LA, McNulty S, Neilson RP (2000) The interplay between climate change, forests, and disturbances. Sci Total Environ 262:201-204

Fischlin A, Gyalistras D (1997) Assessing impacts of climate change on forests in the Alps. Global Ecol Biogeogr Lett 6:19-37

FOWG (2000) Hydrologisches Jahrbuch der Schweiz (Hydrological yearbook of Switzerland). Federal Office for Water and Geology, Swiss Hydrological Survey, Berne

Frei C, Davies HC, Gurtz J, Schär C (2001) Climate dynamics and extreme precipitation and flood events in Central Europe. Integr Assess 1:281-299

GEOSTAT (1992) Die Bodennutzung der Schweiz. Arealstatistik 1992/97 (Swiss land-use statistics 1992/97). Swiss Federal Statistical Office, Berne

GEOSTAT (1994) Digitale Bodeneignungskarte der Schweiz (Digital soil suitability map of Switzerland). Swiss Federal Statistical Office, Neuchâtel

Giorgi F, Mearns LO (2002) Calculation of average, uncertainty range, and reliability of regional climate changes from AOGCM simulations via the 'Reliability Ensemble Averaging' (REA) method. J Clim 15:1141-1158

Giorgi F, Hewitson B, Christensen J, Hulme M and 5 others (2001) Regional climate information - evaluation and projections. In: Houghton JT, Ding Y, Griggs DJ, Noguer M, van der Linden PJ, Dai X, Maskell K, Johnson CA (eds) Climate change 2001: the scientific basis. Contribution of Working Group I to the Third Assessment Report of the Intergovernmental Panel on Climate Change. Cambridge University Press, Cambridge, p 583-688

Green WH, Ampt GA (1911) Studies of soil physics. Part 1. The flow of air and water through soils. J Agricult Soc 4:1-24 
Gurtz J, Baltensweiler A, Lang H, Menzel L, Schulla J (1997) Auswirkungen von klimatischen Variationen auf den Wasserhaushalt und Abfluss im Flussgebiet des Rheins (The impact of climatic variations on the water balance and runoff regime in the Rhine river basin). Schlussbericht NFP 31. Swiss Federal Institute of Technology, Zürich

Gurtz J, Baltensweiler A, Lang H (1999) Spatially distributed hydrotope-based modelling of evapotranspiration and runoff in mountainous basins. Hydrol Process 13:2751-2768

Gurtz J, Zappa M, Jasper K, Lang H, Badoux A, Verbunt M, Vitvar T (2003) A comparative study in modelling runoff and its components in two mountainous catchments. Hydrol Process 17(2):297-311

Gyalistras D (2000) Klimaszenarien für den Alpenraum und die Schweiz: Neuester Stand und Vergleich (Climate scenarios for the Alps and Switzerland: state of the art and comparison). In: Wanner H, Gyalistras D, Luterbacher J, Rickli R, Salvisberg E, Schmutz C (eds) Klimawandel im Schweizer Alpenraum. Hochschulverlag AG an der ETH Zürich, p 197-235

Gyalistras D (2002) An uncertainty analysis of monthly temperature and precipitation scenarios for Switzerland. Internal report, Climatology and Meteorology Research Group, University of Bern

Gyalistras D (2003) Development and validation of a highresolution monthly gridded temperature and precipitation data set for Switzerland (1951-2000). Clim Res 25(1):55-83

Gyalistras D, von Storch H, Fischlin A, Beniston M (1994) Linking GCM-simulated climatic changes to ecosystem models: case studies of statistical downscaling in the Alps. Clim Res 4:167-189

Gyalistras D, Schär C, Davies HC, Wanner H (1998) Future Alpine climate. In: Cebon P, Dahinden U, Davies HC, Imboden D, Jaeger JC (eds) Views from the Alps: regional perspectives on climate change. MIT Press, Boston, p 171-223

Hamlet AF, Lettenmaier DP (1999) Effects of climate change on hydrology and water resources in the Colmbia River Basin. J Am Water Res Assoc 35:1597-1623

Hamlet AF, Fluharty D, Lettenmaier DP, Mantua N, Miles E, Mote P, Binder LW (2001) Effects of climate change on water resources in the Pacific Northwest: impacts and policy implications. CIG Publication No. 145, JISAO Climate Impacts Group, University of Washington, Seattle

Houghton JT, Callander BA, Varney SK (eds) (1992) Climate change 1992: the supplement report to the IPCC scientific assessment. Cambridge University Press, Cambridge

Houghton JT, Ding Y, Griggs DJ, Noguer M, van der Linden PJ, Dai X, Maskell K, Johnson CA (eds) (2001) Climate change 2001: The scientific basis. Contribution of Working Group I to the Third Assessment Report of the Intergovernmental Panel on Climate Change. Cambridge University Press, Cambridge

Hulme M, Conway D, Brown O, Barrow E (1994) A 1961-1990 baseline climatology and future climate change scenarios for Great Britain and Europe. Part III: Climate change scenarios for Great Britain and Europe. Climatic Research Unit, University of East Anglia, Norwich

Jasper K (2001) Hydrological modelling of Alpine river catchments using output variables from atmospheric models. PhD dissertation ETH No. 14385, Swiss Federal Institute of Technology (ETH), Zürich

Jasper K, Gurtz J, Lang H (2002) Advanced flood forecasting in Alpine watersheds by coupling meteorological observations and forecasts with a distributed hydrological model. J Hydrol 267:40-52

Jones TC and 11 others (2001) Anthropogenic climate change for 1860 to 2100 simulated with the HadCM3 model under updated emission scenarios. Hadley Centre Technical Note 22, Met Office, Bracknell

Keller F, Lischke H, Mathis T, Möhl A, Wick L, Ammann B, Kienast F (2002) Effects of climate, fire, and humans on forest dynamics: forest simulations compared to the palaeological record. Ecol Model 152:109-127

Kernen R, Gyalistras D (2002) GCMDAT Version 1.1-A data base of General Circulation Model results. Internal report, Climatology and Meteorology Research Group, University of Bern

Kleinn J (2002) Climate change and runoff statistics in the Rhine Basin: a process study with a coupled climate-runoff model. PhD dissertation ETH No. 14663, Swiss Federal Institute of Technology (ETH), Zürich

Klok EJ, Jasper K, Roelofsma KP, Badoux A, Gurtz J (2001) Distributed hydrological modelling of a glaciated Alpine river basin. Hydrol Sci J 46(4):553-570

Legates DR, McCabe GJ (1999) Evaluating the use of 'goodness-of-fit' measures in hydrologic and hydroclimatic model validation. Water Resour Res 35:233-241

Leung LR, Wigmosta MS (1999) Potential climate change impacts on mountain watersheds in the Pacific Northwest. J Am Water Resour Assoc 35:1463-1471

Martignoni M, Barelli P (1997) Impianti idroelettrici in Ticino e Mesolcina (Hydropower plants in the Ticino area) In: Elettricità Svizzera Italiana (ESI) (eds) Dipartimento del territorio, Departimento delle finanze e dell'economia, Bellinzona

McCarthy JJ, Canziani OF, Leary NA, Dokken DJ, White KS (eds) (2001) Climate change 2001: impacts, adaptation, and vulnerability. Contribution of Working Group II to the Third Assessment Report of the Intergovernmental Panel on Climate Change. Cambridge University Press, Cambridge

Mearns LO, Hulme M, Carter TR, Leemans R, Lal M, Whetton P (2001) Climate scenario development. In: Houghton JT, Ding Y, Griggs DJ, Noguer M, van der Linden PJ, Dai X, Maskell K, Johnson CA (eds) Climate change 2001: the scientific basis. Contribution of Working Group I to the Third Assessment Report of the Intergovernmental Panel on Climate Change. Cambridge University Press, Cambridge, $\mathrm{p} 739-768$

Menzel L, Bürger G (2002) Climate change scenarios and runoff response in the Mulde catchment (Southern Elbe, Germany). J Hydrol 267:53-64

Menzel L, Lang H, Rohmann M (1999) Mittlere jährliche aktuelle Verdunstungshöhen 1973-1992 (Mean annual evapotranspiration in Switzerland for 1973-1992). In: Hydrologischer Atlas der Schweiz, Plate 4.1. Swiss National Hydrological Survey, Berne

Menzel L, Niehoff D, Bürger G, Bronstert A (2002) Climate change impacts on river flooding: a modelling study of three meso-scale catchments. In: Beniston M (ed) Climatic change: implications for the hydrological cycle and for water management. Advances in Global Research, Vol 10, Kluwer, Dordrecht, p 249-269

Monteith JL (1975) Vegetation and the atmosphere. Vol 1: Principles. Academic Press, London

Nakicenovic N, Swart R (eds) (2000) Special report on emission scenarios. Cambridge University Press, Cambridge

Nash JE, Sutcliffe JV (1970) River flow forecasting through conceptual models. 1. A discussion of principles. J Hydrol 10(3):282-290

Oke TR (1987) Boundary layer climates, 2nd edn. Routledge, London

Peschke G (1987) Soil moisture and runoff components from 
a physically founded approach. Acta Hydrophys 31(3/4): 191-205

Richards LA (1931) Capillary conduction of liquids through porous mediums. Physics 1:318-333

Schaper J, Seidel K (2001) Modelling daily runoff from snow and glacier melt using remote sensing data. In: Wunderle $\mathrm{S}$, Nagler T (eds) Proceedings of the 2nd EARSel Workshop - Special Interest Group Land Ice and Snow, June 2000, Dresden. eProceedings Vol 1, Paris, p 308-316

Schär C, Lüthi D, Beyerle U, Heise E (1999) The soilprecipitation feedback: a process study with a regional climate model. J Clim 12:722-741

Schär C, Vidale PL, Lüthi D, Frei C, Häberli C, Liniger M, Appenzeller $C$ (2004) The role of increasing temperature variability in European summer heatwaves. Nature 427: 332-336

Schmidli J, Schmutz C, Frei C, Wanner H, Schär C (2002) Mesoscale precipitation variability in the region of the European Alps during the 20th century. Int J Climatol 22:1049-1074

Schulla J (1997) Hydrologische Modellierung von Flussgebieten zur Abschätzung der Folgen von Klimaänderungen (Hydrological modelling of river basins for estimating the effects of climate change). Zürcher Geographische Schriften 69, Swiss Federal Institute of Technology (ETH), Zürich

Schulla J, Jasper K (2000) Model Description WaSiM-ETH. Institute for Atmospheric and Climate Science, Swiss Federal Institute of Technology, Zürich

Schwarb M, Daly C, Frei C, Schär C (2001) Mean seasonal precipitation throughout the European Alps 1971-1990. In: Hydrological Atlas of Switzerland, Plate 2.7. Swiss National Hydrological Survey, Berne

Editorial responsibility: Hans von Storch, Geesthacht, Germany
Seneviratne SI, Pal JS, Eltahir EAB, Schär C (2002) Summer dryness in a warmer climate: a process study with a regional climate model. Clim Dyn 20:69-85

Sevruk B (ed) (1986) Correction of precipitation measurements. Zürcher Geographische Schriften 23, Swiss Federal Institute of Technology (ETH), Zürich

SFOT (1992) Digital Height Model RIMINI. Product Information. Swiss Federal Office of Topography, Wabern

Snover AK, Hamlet AF, Lettenmaier DP (2003) Climatechange scenarios for water planning studies: Pilot applications in the Pacific Northwest. Bull Am Meteorol Soc 84(11):1513-1518

Trenberth K, Paolino DA (1980) The northern hemisphere sea-level pressure data set: trends, errors and discontinuities. Mon Weather Rev 108:855-872

Trigo RM, Palutikof JP (2001) Precipitation scenarios over Iberia: a comparison between direct GCM output and different downscaling techniques. J Clim 14:4422-4446

Verbunt M, Gurtz J, Jasper K, Lang H, Warmerdam P, Zappa M (2003) The hydrological role of snow and glaciers in alpine river basins and their distributed modelling. J Hydrol 182:36-55

von Storch H, Zwiers FW (1999) Statistical analysis in climatic research. Cambridge University Press, Cambridge

Widmann M, Bretherton CS (2000) Validation of mesoscale precipitation in the NCEP reanalysis using a new gridpoint data set for the northwestern US. J Clim 13(11): 1936-1950

Wigley TML, Raper SCB (2001) Interpretation of high projections for global-mean warming. Science 239:451-454

Wild M, Dümenil L, Schulz JP (1996) Regional climate simulation with a high resolution GCM: surface hydrology. Clim Dyn 12:755-774

Submitted: March 17, 2003; Accepted: February 4, 2004 Proofs received from author(s): April 28, 2004 